\title{
Related Contacts and Personal Jurisdiction: The "But For" Test
}

\author{
Flavio Rose
}

Personal jurisdiction over a defendant exists if one of two tests is met, that of general or specific jurisdiction. General jurisdiction exists if the defendant's contacts with the forum are continuous and systematic. Specific jurisdiction exists when (1) the defendant has contacts with the forum which are related to the cause of the action, (2) those contacts amount to purposeful availment of the privilege of conducting activities within the forum, and (3) the exercise of jurisdiction is reasonable. This Comment explores the first aspect of the specific jurisdiction test: the relatedness inquiry. The Supreme Court has not defined "related" for purposes of specific jurisdiction, leaving the lower courts to search for working definitions on their own. This Comment examines the Ninth Circuit's "but for" test of relatedness, as well as alternatives to that test, in light of the policies personal jurisdiction law is designed to serve. The author argues that the policies which are generally agreed to underlie personal jurisdiction doctrine are so general that they do not suggest any specific rules. Moreover, the author argues that none of the relatedness tests thus far advanced are entirely satisfactory. The author endorses a baseline rule for relatedness based on whether a defendant's contacts with a forum are relevant to the substantive elements of the causes of action pursued by the plaintiff. However, because this baseline rule will not produce satisfactory results in all types of cases, the author proposes limited exceptions, as well as a guideline for the creation of new exceptions.

\section{INTRODUCTION}

Personal jurisdiction is widely regarded as a problematic, uncertain, and murky area of the law. ${ }^{1}$ It encompasses several distinct doctrinal and

Copyright $\odot 1994$ California Law Review, Inc.

$\dagger$ Law clerk to the Honorable Irma E. Gonzalez, United States District Judge, Southern District of California. J.D. 1994, Boalt Hall School of Law, University of California, Berkeley. I would like to thank Professor Jan Vetter for his advice and guidance and Stephanie Powers-Skaff for her editing.

1. Personal jurisdiction law is briefly summarized infra Part I. For a comprehensive treatment of personal jurisdiction, see ROBERT C. CASAD, JuRISDICTION IN Crvm ACtions (2d ed. 1991). 
policy conundrums. This Comment analyzes one of them, the notion of related contacts. ${ }^{2}$

The existence of personal jurisdiction over an out-of-state defendant often turns on whether the defendant's contacts with the forum are considered "related" to the cause of action. For example, suppose that a traveler reserves a room at a hotel im a different state, goes there, and suffers a slip and fall. Will the traveler be able to sue the hotel in her own state? Jurisdiction, im such a case, may ultimately turn on whether the hotel's acceptance of a reservation from the traveler's state is related to the slip and fall.

In 1984, the Supreme Court explicitly left explanations of the meaning of "related" for a later day, ${ }^{3}$ which has not yet arrived. Most circuits have applied the concept of related contacts without giving an explicit definition of "related." In 1990, however, the Nintl Circuit in Shute v. Carnival Cruise Lines 4 defined a "related" contact to be one which is a "but for" cause of the alleged injury. ${ }^{5}$ As the court noted at the time, this definition can lead to results different from those reached in other circuits. ${ }^{6}$

This Comment analyzes and criticizes the "but for" test for related contacts. Part I summarizes personal jurisdiction law so that the reader can understand the role relatedness plays. Part $\Pi$ then explains the policy bases for the law of personal jurisdiction. With this background, Part III discusses the "but for" test and its limitations. Part IV then analyzes what alternative tests might be used for relatedness. This analysis suggests that no single test is likely to be appropriate in all situations. Consequently, Part $V$ recommends the adoption of a baseline relatedness test together with specific exceptions for particular legal subject areas. Part V also argues that the fact situation of Shute merits a specific exception.

\section{I}

\section{Summary of Personal Jurisdiction Law}

\section{A. The Origins of Modern Personal Jurisdiction Law}

The Supreme Court laid the bases for modern personal jurisdiction law in four decisions handed down between 1945 and 1958: International Shoe

2. For brief discussions of some of these other conundrums, see infra text accompanying notes 75-80 (purposeful availment); infra text accompanying notes 116-22 (the "consent/exchange" policy justification for personal jurisdiction rules).

3. Helicopteros Nacionales de Colombia, S.A. v. Hall, 466 U.S. 408,415 n.10 (1984).

4. 897 F.2d 377 (9th Cir. 1990), rev'd on other grounds, 499 U.S. 585 (199I). The Supreme Court reversed Shute because the contract at issue contained a forum selection clause which the Supreme Court, unlike the court of appeals, found valid. Carnival Cruise Lines v. Shute, 499 U.S. 585, 595 (1991). Because the Court was thus able to dispose of the case on nonconstitutional grounds, it did not reach the pcrsonal jurisdiction issue. Id. at 589 .

5. 897 F.2d at 385 .

6. Id. at $383-86$. 
Co. v. Washington, ${ }^{7}$ Perkins v. Benguet Consolidated Mining Co., ${ }^{8}$ McGee v. International Life Insurance Co., ${ }^{9}$ and Hanson v. Denckla. ${ }^{10}$ Each of these decisions established basic principles which have guided more recent developments in personal jurisdiction law.

International Shoe established that personal jurisdiction rules must focus on the defendant's contacts with the forum state. ${ }^{11}$ The state of Washington had sued the International Shoe Company in its own courts in an attempt to compel the company to pay state unemployment tax. International Shoe sold goods in Washington and had sales representatives based there, on whose salaries the state sought to assess unemployment tax. However, the company defended the suit on the ground that its "presence" in the state was insufficient for personal jurisdiction. ${ }^{12}$

The Court in International Shoe cast aside the "presence" rules which had developed over the preceding decades. ${ }^{13}$ "Presence," the Court determined, is "used merely to symbolize those activities of the corporation's agent within the state which courts will deem to be sufficient to satisfy the demands of due process."14 Accordingly, the Court held that personal jurisdiction existed because the defendant had "minimum contacts" with the state, "such that the maintenance of the suit does not offend "traditional notions of fair play and substantial justice." "15 On that basis it found that the state of Washington could properly exercise personal jurisdiction over International Shoe.

In Perkins v. Benguet Consolidated Mining Co., the Supreme Court expanded on the "contacts" requirement, ruling that if a defendant has sufficient contacts with the forum state, personal jurisdiction can exist over the defendant for a cause of action unrelated to those contacts. ${ }^{16}$ The defendant in Perkins was a Philippine corporation doing busimess in the Philippines before the Second World War. When Japan invaded that country, the defendant moved its headquarters to Ohio. ${ }^{17}$ The plaintiff sued the defend-

\footnotetext{
7. 326 U.S. 310 (1945).

8. 342 U.S. 437 (1952).

9. 355 U.S. 220 (1957).

10. 357 U.S. 235 (1958).

11. 326 U.S. at 316.

12. Id. at 315 .
}

13. Id. at 316-17. Under the older view, jurisdiction over out-of-state corporations had to be based cither on their presence in the state or on their express or implied consent to jurisdiction. See, e.g., Pennsylvania Fire Ins. Co. v. Gold lssue Mining \& Milling Co., 243 U.S. 93, 95-96 (1917) (finding consent to personal jurisdiction where an agent was appointed to accept service of process within the forum state); St. Louis S.W. Ry. v. Alexander, 227 U.S. 218, 226 (1913) (finding jurisdiction based upon the defendant's "presence" in the forum state); 1 CASAD, supra note $1, \$ 2.02[3][\mathrm{c}][i i]$; William F. Cahill, Jurisdiction over Foreign Corporations and Individuals Who Carry On Business Within the Territory, 30 HARv. L. Rev. 676, 678, 696 (1917).

14. International Shoe, 326 U.S. at 316-17.

15. Id. at 316 (quoting Milliken v. Meyer, 311 U.S. 457, 463 (1940)).

16. 342 U.S. $437,446-47$ (1952) (quoting International Shoe, 326 U.S. at 318-19).

17. Id. at $447-48$. 
ant in Ohio on a cause of action admittedly unrelated to its Ohio activities. The Supreme Court listed the defendant's numerous activities im Ohio and held that it would not violate federal due process for Ohio to exercise jurisdiction over the defendant. ${ }^{18}$

McGee v. International Life Insurance Co. established that a single contract, entered into by mail with a forum resident, could meet the minimum contacts test for a suit on the contract. ${ }^{19}$ The defendant bought an Arizona insurance company that had written a policy for the plaintiff's husband, a California resident. ${ }^{20}$ The defendant subsequently renewed that pohicy, thus entering into a contract with the husband. ${ }^{21}$ The defendant never had an office or an agent in California, and had never solicited or done any insurance business in California apart from the policy involved in the case. ${ }^{22}$ Nonetheless, the Supreine Court found personal jurisdiction. Justice Black wrote that "[i]t is sufficient for purposes of due process that the suit was based on a contract which had substantial connection with that State."23

Fimally, in Hanson v. Denckla, the Supreme Court established two important principles to guide application of the new "contact" rules. First, "[t]he umilateral activity of those who claim some relationship with a nonresident defendant" cannot count against that defendant as a forun contact. ${ }^{24}$ Second, the exercise of personal jurisdiction requires that "there be some act by which the defendant purposefully avails itself of the privilege of conducting activities within the forum State, thus invoking the benefits and protections of its laws."25

The issue in Hanson was the existence of personal jurisdiction over a trustee, a Delaware trust company, in Florida. The suit challenged the appoimtinent of a beneficiary of the trust. The settlor had established that trust while living in Pennsylvania, but eventually moved to Florida. ${ }^{26}$ While in Florida, the settlor executed trust instruments retaming a power of appointinent over the trust property and appointing a portion of the property to certain beneficiaries. ${ }^{27}$ In finding that Florida courts did not have jurisdiction over the Delaware trustee, the Supreme Court found the crueial dis-

18. Id. at 448. Unfortunately, the Court did not elaborate on the standard it was applying in reaching its decision.

19. 355 U.S. 220,223 (1957).

20. Id. at $221-22$.

21. Id.

22. Id. at 222 .

23. Id. at 223. This reasoning appears to stem from International Shoe, where the Court spoke of "obligations [which] arise out of or are connected with [defendant's] activities within the state." 326 U.S. at 319. The Court in International Shoe further stated that suits in the state to enforce such obligations would not violate due process "in most instances." Id.

24. 357 U.S. 235, 253 (1958).

25. Id.

26. Id. at 238-39.

27. Id. at 239. 
tinction between Hanson and McGee lay in the fact that the insurance company in McGee had solicited the California resident's business in California, whereas the trustee had entered into its relationship with the settlor before she moved to Florida. ${ }^{28}$ The Court noted that "[ $\left.t\right]$ he cause of action ... is not one that arises out of an act done or transaction consummated in the forum State. ${ }^{29}$

\section{B. The Prevailing Test for Personal Jurisdiction}

During the twenty years following the four cases just discussed, the Supreme Court did not decide any personal jurisdiction cases. Consequently, personal jurisdiction law was developed by the lower courts and commentators. During this time, the following personal jurisdiction test achieved widespread support:

(a) Personal jurisdiction exists over the defendant if the defendant meets one of two tests: general jurisdiction or specific jurisdiction.

(b) General jurisdiction exists over a defendant if its contacts with the forum state are continuous and systematic.

(c) Specific jurisdiction exists over a defendant if:

(1) it has contacts with the forum state which are related to the cause of action,

(2) those contacts amount to purposeful availment of the privilege of conducting activities within the forum state, and

(3) the exercise of jurisdiction appears reasonable to the court based on a weighing of factors similar to those used by federal courts in deciding forum non conveniens ${ }^{30}$ niotions.

This Comment refers to this test as the "prevailing test" for personal jurisdiction, in recognition of its widespread, but not complete, acceptance.

The prevailing test builds on the four key Supreme Court cases described in the preceding section. Part (b) is based on Perkins v. Benguet Consolidated Mining Co. ${ }^{31}$ Part (c)(1) relies on the references to related contacts in International Shoe and McGee. ${ }^{32}$ Part (c)(2) incorporates the purposeful availment requirement set fortl in Hanson. ${ }^{33}$ Part (c)(3) is not as clearly rooted in these cases but has nonetheless achieved widespread acceptance. ${ }^{34}$

28. Id. at 251-52.

29. Id. at 251 .

30. The doctrine of forum non conveniens permits a federal court to refuse to hear a case under certain circumstances when a different forum would be more appropriate. Piper Aircraft Co. v. Reyno, 454 U.S. 235, 249 (1981); see also 1 CASAD, supra note 1, § 1.04.

31. See supra notes $16-18$ and accompanying text.

32. See supra notes 11-14, 19-23 and accompanying text.

33. See supra text accompanying notes $24-28$.

34. See Leslie W. Abramson, Clarifying "Fair Play and Substantial Justice": How the Courts Apply the Supreme Court Standard for Personal Jurisdiction, 18 HAstangs Const. L.Q. 441 passim 
The distinction between general and specific jurisdiction, as in parts (a) and (b), is generally attributed to Professors von Mehren and Trautman, writing in $1966 .{ }^{35}$ Courts started using the terms general and specific jurisdiction soon afterward, ${ }^{36}$ but the idea behind the distinction had already been set out in International Shoe. ${ }^{37}$

Part (c) apparently first appeared in 1958, in a student note published soon after the decisions in McGee and Hanson. ${ }^{38}$ The Ninth Circuit immediately cited the Georgetown students' formulation with approval. ${ }^{39}$ Eventually, the Sixth and Ninth Circuits formally adopted versions of the prevailing test. ${ }^{40}$ At a later time, after the Supreme Court returned to the issue of personal jurisdiction, the First and Third Circuits would adopt similar tests. ${ }^{41}$ Other courts of appeal have applied the prevailing test without formally adopting it. ${ }^{42}$

(1991) (citing numerous reasonableness cases). The reasonableness fork of the prevailing test is often called "fair play and substantial justice."

35. Arthur T. von Mehren \& Donald T. Trautman, Jurisdiction to Adjudicate: A Suggested Analysis, 79 HARv. L. Rev. 1121, 1141-63 (1960).

The phrases "general jurisdiction" and "specific jurisdiction" introduced by Profcssors von Mehren and Trautman presumably derive from the analogous German terms "allgemeiner Gerichtsstand" and "besonderer Gerichtsstand." Professor von Mehren was well acquainted with German civil procedure, having made a special study of it in the 1950s. See Benjamin Kaplan et al., Phases of German Civil Procedure (pts. 1 \& 2), 71 HARv. L. Rev. 1193, 1443 (1958) (coauthored by von Mehrcn).

"Allgemeiner Gerichtsstand" is used by the German code of civil procedure to refer to territorial jurisdiction extending to all causes of action against a particular defendant. ZiviLPROzESSORDNUNO $\$ 12$ (F.R.G.). "Besonderer Gerichtsstand" has long been used by courts and commentators to denote territorial jurisdiction cxtending only to certain causes of action. E.g., L. Busch \& W. KrANTz, ZIVILROZESSORDNUNG UND GERICHTSVERPASSUNGSGESETZ 53 (17th ed. 1922).

36. See Mary Twitchell, The Myth of General Jurisdiction, 101 HARv. L. Rev. 610, 628 n.84 (1988); cf. Japan Gas Lighter Ass'n v. Ronson Corp., 257 F. Supp. 219, 232 n.24 (D.N.J. 1966) (citing von Mehren \& Trautman, supra note 35); id. at 234-35 (analyzing jurisdiction in terms of purposeful availment and "arising out of").

37. International Shoe Co. v. Washington, 326 U.S. 310, 316-17 (1945).

38. Bert Harte et al., Note, Jurisdiction over Nonresident Corporations Based on a Single Act: $A$ New Sole for International Shoe, 47 GEO. L.J. 342, 351-52 (1958). The Note formulated the test as three rules. Rule 1 required that the defendant perform some act within the forum; the Note explaincd that this could be done by mail, and connected the requirement to purposeful availment. Id. at 352-53. Rule 2 was relatedness, and required that the cause of action arise out of, or result from, the defendant's activities within the forum. Id. at 353-55. Rule 3 referred to a "substantial minimum contact" between the defendant and the forum state and was described as analogous to forum non conveniens. Id. at 35659.

39. L.D. Rceder Contractors v. Higgins Indus., 265 F.2d 768, 773-74 n.12 (9th Cir. 1959).

40. Data Disc, Inc. v. Systems Technology Assocs., 557 F.2d 1280, 1287 (9th Cir. 1977); Southern Mach. Co. v. Mohasco Indus., 401 F.2d 374, 381 (6th Cir. 1968).

41. United Elec. Workers v. 163 Pleasant St. Corp., 960 F.2d 1080, 1089 (1st Cir. 1992); Dollar Sav. Bank v. First Sec. Bank, 746 F.2d 208, 211-13 (3d Cir. 1984).

42. See, e.g., Command-Aire Corp. v. Ontario Mechanical Sales \& Serv., 963 F.2d 90, 94-95 (5th Cir. 1992) (utilizing a reasoning pattern similar to a prevailing test analysis in deciding the personal jurisdiction issue). 


\section{More Recent Supreme Court Personal Jurisdiction Cases}

In a number of personal jurisdiction cases decided between $1977^{43}$ and $1990,{ }^{44}$ the Supreme Court refined the principles of personal jurisdiction law which it had set forth between 1945 and 1958. This Section discusses three of the most significant cases.

In Helicopteros Nacionales de Colombia, S.A. v. Hall, ${ }^{45}$ the Supreme Court adopted the general and specific jurisdiction distinction previously employed by lower courts and commentators. The defendant was a Colombian aviation services company, which had entered into a contract with a Texas joint venture to provide helicopter services in Peru. ${ }^{46}$ The plaintiffs' decedents had worked for the Texas joimt venture and had died in a crash of one of the Colombian helicopters in Peru. The helicopter that crashed had been purchased in Texas. ${ }^{47}$

The plaimtiffs sued the Colombian company in Texas. ${ }^{48}$ The plaintiffs' lawyers appear to have conceded at some poimt that the Colombian company's contacts with Texas were unrelated to the cause of action. ${ }^{49}$ Accordingly, for the first time simce Benguet, the Court was compelled to decide whether the defendant's forum contacts met the general jurisdiction test. Formulating that test as requiring "continuous and systematic" contacts, the Court decided that Hehicópteros' contacts failed to meet the test. ${ }^{50}$

In Burger King Corp. v. Rudzewicz, ${ }^{51}$ the Supreme Court explored the ineaning of purposeful availment im a contract case. The defendants, residents of Michigan, had entered into a franchise agreement with Burger King Corporation to set up a Burger King restaurant in that state. Burger King sued them in Florida, the site of its headquarters, for breach of that agreement. . $^{52}$

The Court's opinion reaffirmed the general rule that specific jurisdiction exists where "the defendant has 'purposefully directed' his activities at residents of the forum ... and the litigation results from alleged imjuries that 'arise out of or relate to' those activities." 53 The Court also held that "an individual's contract with an out-of-state party alone" cannot "automati-

43. Shaffer v. Heitner, 433 U.S. 186 (1977).

44. Burnham v. Superior Court, 495 U.S. 604 (1990).

45. 466 U.S. 408 (1984).

46. Id. at 409-10.

47. Id. at 426 (Brennan, J., dissenting).

48. Id. at 412 .

49. Id. at 415 \& n.10. But see id. at 425 n.3 (Brennan, J., dissenting) (disputing that such a concession was made). The defendant's CEO had visited Texas to negotiate the contract with the Texas joint venture and the defendant's employees were trained on the use of the helicopters in Texas. Id. at 416.

50. Id. at 416.

51. 471 U.S. 462 (1985).

52. Id. at $466-68$.

53. Id. at 472 (quoting Keeton v. Hustler Magazine, 465 U.S. 770, 774 (1984) and Helicopteros Nacionales de Colombia, S.A. v. Hall, 466 U.S. 408,414 (1984)). 
cally establish sufficient mininum contacts" in the other party's forum state, thereby giving rise to personal jurisdiction. ${ }^{54}$ To determine whether a contract amounts to "the defendant purposefully establish[ing] inininum contacts within the forum," courts must take into account a number of factors: "prior negotiations and contemplated future consequences, along with the terms of the contract and the parties' actual course of dealing." 55 In Burger King, these factors poimted to the existence of personal jurisdiction.

The Court also found Florida's exercise of personal jurisdiction over the defendants to be reasonable. ${ }^{56}$ In arriving at this decision, the Court confirmed that the reasonableness inquiry is separate froin the purposeful availment analysis, stating that the exercise of jurisdiction might not be reasonable "even if the defendant has purposefully engaged in forum activities."

The Suprene Court again confirmed the independence of the reasonableness inquiry in Asahi Metal Industry Co. v. Superior Court. ${ }^{58}$ In Asahi, a Taiwanese tire manufacturer was the defendant in a California products liability case. The tire manufacturer cross-claimed agamst Asahi, a Japanese company which had sold it an allegedly defective tire valve. ${ }^{59}$ Eight Justices held that the exercise of personal jurisdiction over the Japanese company was unreasonable, primarily, it seems, because both the plaintiff and the defendant were foreigners. ${ }^{60}$

In summary, recent Supreme Court case law has largely confirmed the prevailing test. In doing so, the Court has categorically distinguished between general and specific jurisdiction and has also established the reasonableness imquiry as an mdependent fork of the personal jurisdiction test. Most importantly, the Court has made it clear that defendants' related forum contacts must meet the purposeful availment threshold for there to be specific jurisdiction. ${ }^{61}$

54. Id. at 478 .

55. Id. at 479.

56. Id. at 481-87.

57. Id. at 477-78. Since the Supreme Court's decision in Burger King, the Ninth Circuit has slightly altered its version of the prevailing test. In Haisten v. Grass Valley Medical Reimbursement Fund, 784 F.2d 1392 (9th Cir. 1986), the court held that, under Burger King, a finding of purposeful availment gives rise to a presumption of reasonableness, which the defendant bears the burden of overcoming. Id. at 1397. The Third and Sixth Circuits, which had also formally adopted versions of the prevailing test before Burger King, do not seem to have followed suit.

58. 480 U.S. 102 (1987) (plurality opinion).

59. Id. at 106.

60. Id. at 114-16.

61. "[F]or those in search of something certain in the mass of confusion, the jumble does reveal one abiding jurisdictional truth: the defendant must have "purposefully availed." " Margaret G. Stewart, A New Litany of Personal Jurisdiction, 60 U. CoLo. L. REv. 5, 6 (1989); see also Earl M. Maltz, Reflections on a Landmark: Shaffer v. Heitner Viewed from a Distance, 1986 B.Y.U. L. REv. 1043, 1059-60 (arguing that purposeful availment is the key concept in the Supreme Court's recent personal jurisdiction case law).

In a sense, International Shoe, Helicopteros, and Burger King alone compel the prevailing personal jurisdiction test. International Shoe instructs courts to focus on the defendant's contacts. See supra text 


\section{Applying the Prevailing Personal Jurisdiction Test}

\section{An Example: Roth v. Garcia Marquez}

The application of the prevailing test for personal jurisdiction is illustrated by a recent case, Roth $v$. Garcia Marquez, ${ }^{62}$ where the named defendant was the well-known Colombian novelist. Roth tried through faxes, phone calls, and meetings (including two in the forum state, Cahifornia) to get the movie rights to Love in the Time of Cholera. He and García Márquez eventually reached an agreement in principle, but were unable to agree on the terms of the final contract. Roth sued, claiming that the agreement in principle was binding. ${ }^{63}$

Roth conceded that García Márquez, who lived in Mexico, was not subject to general jurisdiction in the forum. ${ }^{64}$ For the specific jurisdiction analysis, the agreement in principle itself was obviously a forum contact related to the cause of action. ${ }^{65}$ The in-forum meetings were also arguably related.

The court found the purposeful availment inquiry to be "a very close call," particularly in light of Roth's "sedulous efforts of solicitation." 66 Nonetheless, the court found for Roth mainly because "all of the editing, production work, and advertising" would be performed in California. ${ }^{67}$ Reasonableness was another "extremely close question" due to the heavy burden jurisdiction would impose upon García Márquez. ${ }^{68}$ The court ultimately decided this issue in Roth's favor as well.69

Applying the prevailing test requires an understanding of the following terms or phrases: "contact," "continuous and systematic," "related contact," "purposeful availment," and "reasonable exercise of jurisdiction." The meaning of "related contact" is the subject of this Comment and is discussed im detail in Parts III, IV, and V. Before beginning that discussion, lowever, this Comment provides a brief overview of the other key terms.

accompanying note 15 . Helicopteros instructs courts to measure those contacts against different thresholds according to whether the cause of action is related to the contacts or not. See supra text accompanying note 50. Burger King completes the picture by labeling the related contacts threshold "purposeful availment," and requiring a reasonableness analysis. See supra text accompanying notes 53-57.

62. 942 F.2d 617 (9th Cir. 1991).

63. Id. at 619-20.

64. Id. at 620 .

65. Id. at 619-20.

66. Id. at 622 .

67. Id.

68. Id. at 625 .

69. Id. at 625. This aspect of the decision is questionable, however, since the court found that three of the factors in its reasonableness test favored Garcia Márquez and only two favored Roth. Id. Roth eventually lost on the substantive claim. Id. at 628-29. 


\section{Contacts}

Acts physically performed in the forum are contacts. Acts performed outside the forum are also contacts when the defendant has performed thein with some degrce of awareness that the acts would have an effect in the forum. ${ }^{70}$ It remains unclear to what extent a defendant inust be aware of the forum effect, but simple notice that one is dealing with a forum resident is probably not enough. For example, a Nevadan who crashes into a car with California plates in Nevada has probably not established a proper contact with California. ${ }^{71}$

\section{Continuous and Systematic}

The general jurisdiction threshold of "continuous and systematic" contacts typically requires that the defendant have an office in the forum, ${ }^{72}$ though lesser degrees of involvement with the forum have been found suffcient for general jurisdiction. ${ }^{73}$ It is possible to do a fair ainount of business in a state without being subject to general jurisdiction. For exainple, the Fourth Circuit recently held that Maryland could not cxercise general jurisdiction over pharmaceutical giant G.D. Searle, which employed thirteen Maryland residents as sales representatives under the direction of a district inanager. ${ }^{74}$

\section{Purposeful Availment}

Purposeful availment is the inost difficult and important part of the specific jurisdiction test. As with the question of what is a proper contact, purposeful availment turns on the extent to which defendant's involveinent in the forum was intentional. For example, visiting a forum is often considered to be a strong indicator of purposeful availment. ${ }^{75}$ In addition, tele-

70. See, e.g., Lea Brilmayer, How Contacts Count: Due Process Limitations on State Court Jurisdiction, 1980 SuP. CT. REv. 77, 88-96 (discussing competing policies for deciding what contacts are properly "attributable" to a defendant for the purpose of estabhishing personal jurisdiction).

71. Hanson $v$. Denckla laid down the fundamental rule that "[t]he unilateral activity of those who claim some relationship with a nonresident defendant cannot satisfy the requirement of contact with the forum State." 357 U.S. 235, 253 (1958).

72. See Twitchell, supra note 36 , at 635 ("traditional indicia" of general jurisdiction are "a home base, an agent for the service of process, a local office, or the pursuance of business from a tangible locale within the state"). See also generally Lea Brilmayer et al., A General Look at General Jurisdiction, 66 TEX. L. REv. 721 (1988).

73. See Twitchell, supra note 36 , at $635 \mathrm{nn} \cdot 119-20$ (citing cases in which the courts found general jurisdiction absent an office in the forum).

74. Nichols v. G.D. Searle \& Co., 991 F.2d 1195, 1198, 1200 (4th Cir. 1993).

75. Compare Afram Export Corp. v. Metallurgiki Halyps, S.A., 772 F.2d 1358, 1362-64 (7th Cir. 1985) (Posner, J.) (finding that a five-hour visit to the forum created the necessary additional contact to allow jurisdiction over a defendant who bought goods F.O.B. the forum) and Bell Paper Box, lnc. v. U.S. Kids, Inc., 22 F.3d 816, 819-20 (8th Cir. 1994) (relying on a visit to the forum in addition to the fact that the goods were made in the forum and sold to the defendant F.O.B. the forum to find jurisdiction) with Papachristou v. Turbines Inc., 884 F.2d 1116, 1118-19 (8th Cir. 1989) (refusing to 
phone calls into the forum, although usually insufficient, ${ }^{76}$ may in some instances be enough to establish purposeful availment.

A difficult question is whether entering into a contract with a forum resident constitutes purposeful availment. The Supreme Court held in Burger King that the question must be resolved without "'mechanical' tests."77 Instead, courts inust consider "prior negotiations and contemplated future consequences, along with the terms of the contract and the parties' actual course of dealing."78

A second difficult issue, usually referred to as the "stream of commerce" problein, arises in products liability cases. Suppose that A sells its product outside the forum to $B$, who in turn sells that product in the forum, perhaps incorporated into one of its own products. Has A purposefully availed? In Asahi, four Justices, faced with Asahi's claim that it did not know that tires incorporating its valves were being sold in the United States, thought that it had not purposefully availed. ${ }^{79} \mathrm{~A}$ third difficult issue in purposeful availment law is whether a defamation defendant who gives an interview to a publication has purposefully availed itself of any forum where the publication circulates. ${ }^{80}$

The purposeful availment threshold cannot be met with forum activity unrelated to the cause of action. Thus, for example, in Roth v. Garcia Marquez, the Ninth Circuit discounted the defendant's forum visits because they had purposes other than negotiating the contract at issue. ${ }^{81}$ However, in determining whether purposeful availment exists in a particular case, a court may look at other unrelated contacts which shed light on whether the related contacts amount to purposeful availment. Consider, for example, a

find purposeful availment even though defendant's agent attempted to deliver goods to plaintiff in the forum).

76. See Peterson v. Kennedy, 771 F.2d 1244, 1261-62 (9th Cir. 1985), cert denied, 475 U.S. 1122 (1986).

77. Burger King v. Rudzewicz, 471 U.S. 462, 478 (1985).

78. Id. at 479. Courts often look at who made the first move, as the Supreme Court did in McGee. See supra text accompanying note 28 . For a detailed discussion of contract cases, see Stewart, supra note 61 , at $40-46$.

79. Asahi Metal Indus. Co. v. Superior Court, 480 U.S. 102, 112 (1987). Four other Justices thought Asahi had purposefully availed. Id. at 116 . Justice Stevens declined to decide that issue. Id. at 121-22. For an extended discussion of the stream of commerce problem, see Stewart, supra note 61, at 31-38. One reason why products liability cases are difficult is that the substantive law imposes liability irrespective of the defendant's state of mind, and the jurisdictional requirement of "purposeful" availment is at odds with that substantive standard. Cf. Brilmayer, supra note 70, at 94-95 (distinguishing substantive strict liability from strict liability in the context of jurisdictional causation).

80. Compare Sinatra v. National Enquirer, Inc., 854 F.2d 1191, 1195-98 (9th Cir. 1988) (finding purposeful availment because the interview was obviously intended to promote defendant's bnsiness) with Madara v. Hall, 916 F.2d 1510, 1519 (11th Cir. 1990) (finding no purposeful availment because the defendant did not control the publication and because the act of giving the interview did not constitute "continuous and deliberate exploitation" of the forum's market).

81. 942 F.2d 617, 621 (9th Cir. 1991). For another example of how unrelated contacts are excluded from the purposeful availment determination, see Scott v. Breeland, 792 F.2d 925, 928 (9th Cir. 1986) (holding that certain in-forum acts "cannot ... support the exercise of specific jurisdiction" because of their unrelatedness). 
products liability case in which the related contact is the sale of the product in the forum througli distributors. A court might consider product advertisenents which ran in the forum and design modifications made for the forum in order to determine whether the sale amounted to purposeful availment. $^{82}$

\section{Reasonableness}

The reasonableness fork of the specific jurisdiction test is an escape clause that allows courts to decline jurisdiction based on a variety of factors. ${ }^{83}$ Some circuits apply a balancing test for reasonableness. ${ }^{84}$ For example, the First Circuit applies the following "Gestalt factors" when testing for reasonableness:

(1) the defendant's burden of appearing, (2) the forun state's interest in adjudicating the dispute, (3) the plaintiff's interest in obtaining convenient and effective relief, (4) the judicial system's interest in obtaining the most effective resolution of the controversy, and (5) the common interests of all sovereigns in promoting substantive social policies. ${ }^{85}$

The clearest case illustrating an unreasonable exercise of jurisdiction is where botll the plaintiff and the defendant are foreign, as in Asahi.

\section{E. Long-Arm Statutes}

The personal jurisdiction requirements discussed thus far are constitutional limits on the jurisdiction of state courts. The exercise of personal jurisdiction in those courts must also meet any state statutory limits on the exercise of jurisdiction over out-of-state defendants. These statutory limits are referred to as "long-arın statutes."

Personal jurisdiction in federal district courts is also subject to state long-arm statutes and the constitutional limits on state courts' personal jurisdiction for the following reasons. Service of process in federal courts is governed by Federal Rule of Civil Procedure 4. That rule generally allows service only when a state court in the same state as the federal district court could obtain jurisdiction over the defendant. ${ }^{86}$ There are exceptions, ${ }^{87}$ but most cases, particularly those based on state law, do not fall under any of these exceptions. As a result, federal personal jurisdiction

82. See Asahi, 480 U.S. at 112 (finding advertising and design modifications relevant to the purposeful availment inquiry).

83. See generally Abramson, supra note 34.

84. United Elec. Workers v. 163 Pleasant St. Corp., 960 F.2d 1080, 1088 (1st Cir. 1992) (balancing five factors, which the court calls "Gestalt factors"); Roth v. Garcia Marquez, 942 F.2d 617, 623 (9th Cir. 1991) (balancing seven factors).

85. United Elec. Workers, 960 F.2d at 1088.

86. FED. R. Crv. P. 4.

87. The exceptions arc interpleader, 100-mile bulge jurisdiction for parties brought in under Rules 14 and 19 , statutes specifically authorizing nationwide scrvice of process in certain fedcral causcs of 
cases must usually work through state long-arm statutes and then apply the federal constitutional test. ${ }^{88}$

\section{F. Deviations from the Prevailing Test}

The prevailing personal jurisdiction test is not unanimously accepted. Cases that appear to deviate from the test are common, though true deviations are rare. In many cases that appear to deviate from the test, the courts fail to mention the specific/general distinction and relatedness, but nonetheless reach the correct result. This probably occurs because courts prefer to move expeditiously past jurisdictional preliminaries where the existence of personal jurisdiction is intuitively clear. For example, in a recent Supreme Court case, the Court's entire personal jurisdiction discussion consisted of the following two sentences:

[W]e find that Argentina possessed "minimum contacts" that would satisfy the constitutional test. By issuing negotiable debt instruments denommated in U.S. dollars and payable in New York and by appoimting a financial agent in that city, Argentina " "purposefully avail[ed] itself of the privilege of conducting activities within the [Umited States]." "89

True deviations from the prevailing test occur because courts make mistakes and fail to apply the rule developed in Helicopteros. For example, the Seventh Circuit recently exercised personal jurisdiction over a defendant based on periodic visits by the defendant's sales representative to the

action, and defendants not subject to the jurisdiction of the courts of general jurisdiction of any state. FED. R. Crv. P. 4(k); see also I CASAD, supra note 1 , $\$ 5.02$ (f) (discussing the first three exceptions).

88. A state court that exercises personal jurisdiction wrongly over a defendant violates the Constitution. A federal court that does so only violates FED. R. Crv. P. 4 -otherwise there could be no exceptions.

Could the Supreme Court then just amend Rule 4 to eliminate all personal jurisdiction limitations on the federal courts? Leaving aside questions of political feasibility, there are at least three obstacles to the total elimination of personal jurisdiction limitations. First, it is widely believed that the Fifth Amendment Due Process Clause requires that a defendant who is brought into federal court have minimum contacts with the United States as a whole, in the same manner that a defendant in state court must have minimum contacts with the state. See, e.g., Busch v. Buchman, Buchman \& O'Brien, II F.3d 1255,1257 (5th $\mathrm{Cir}$. 1994) (holding that due process requires that a defendant have minimum contacts with the United States). Second, the federal venue statute incorporates personal jurisdiction as part of the venue test in diversity cases, 28 U.S.C. $\$ 1391$ (a)(3) (Supp. V 1993), and incorporates minimum contacts as part of the venue test for corporations, 28 U.S.C. $\$ 1391$ (c) (1988). Third, federal courts in diversity cases apply the choice of law rules of the state in which they sit. Klaxon Co. v. Stentor Elec. Mfg. Co., 313 U.S. 487, 496 (1941). Suppose that a federal court hears a diversity case in a state wliose courts could not constitutionally hear it because of personal jurisdiction limitations, and suppose that the state's choice of law rules point to a law which no state having personal jurisdiction would apply to the case. Under Klaxon, the federal court would nonetheless be compelled to apply that law. The federal court's exercise of personal jurisdiction pursuant to an amended Rule 4 would then, at least arguably, violate the principle that court-made rules like Rule 4 cannot "abridge, enlarge or modify any substantive right." 28 U.S.C. \& 2072(b) (1988).

89. Republic of Argentina v. Weltover, Inc., 112 S. Ct. 2160, 2169 (1992) (quoting Burger King Corp. v. Rudzewicz, 471 U.S. 462, 475 (1985) (quoting Hanson v. Denckla, 357 U.S. 235, 253 (1958)) (bracketed material in the inner quotation added by the Court). 
forum. ${ }^{90}$ The court did not discuss relatedness or the specific/general jurisdiction distinction. The cause of action was apparently unrelated, and the level of forum activity was almost certainly insufficient for general jurisdiction. ${ }^{91}$ Similarly, a recent Eleventh Circuit personal jurisdiction case discussed minimum contacts extensively without inentioning relatedness. ${ }^{92}$ As discussed below, ${ }^{93}$ relatedness was far from obvious based upon the facts of the case.

The Eighth Circuit employs a deviant prinary test for personal jurisdiction, which appears to turn the categorical specific/general distinction into a balancing test, contrary to the holding of Helicopteros. The Eighth Circuit's test considers:

(1) the nature and quality of the contacts with the forum state; (2) the quantity of the contacts with the forum state; (3) the relation of the cause of action to the contacts; (4) the imterest of the foruin state in providing a forum for its residents; and (5) the convenience of the parties. Of these factors, the first three are the most inportant. ${ }^{94}$ The widespread use of this deviant prinary test does not mean, however, that the Eighth Circuit rejects the holding of Helicopteros. In proper cases the Eighth Circuit will apply the specific/general distinction and hold cases without related contacts to a higher standard. ${ }^{95}$ The use of the deviant primary test ineans only that where relatedness is an issue in the Eighth Circuit, lawyers inust draw the court's attention to Helicopteros.

II

\section{The Policies Behind Personal Jurusdiction}

Like the doctrinal rules of personal jurisdiction, the policies behind personal jurisdiction have been the subject of longstanding debate. It has

90. Michael J. Neuman \& Assocs. v. Florabelle Flowers, Inc., 15 F.3d 721 (7th Cir. 1994). The court's discussion of federal due process was three sentences long and cited only a state case and International Shoe. Id. at 725.

91. Contrast the Neuman decision with the Fourth Circuit's refusal to find general jurisdiction over a company that had thirteen sales representatives resident in the forum. Nichols v. G.D. Scarle \& Co., 991 F.2d 1195, 1198 (4th Cir. 1993). For another appellate misundcrstanding of personal jurisdiction law, see Oreck Corp. v. U.S. Floor Sys., Inc., 803 F.2d 166, 169 (5tb Cir. 1986) (describing the relevant long-arm statute as "more restrictive than federal due process" in that it requires "a showing of some connection between the business transacted in Louisiana and the cause of action," suggesting that the court beheved that federal due process does not require such a showing), cert. denied, 481 U.S. 1069 (1987).

92. Vermeulen v. Renault, U.S.A. Inc., 965 F.2d 1014, 1022-28 (1 lth Cir. 1992), superseded, 985 F.2d 1534 (11th Cir. 1993).

93. See infra text accompanying notes 209-14.

94. Dakota Indus., Inc. v. Dakota Sportswear, Inc., 946 F.2d 1384, 1390 (8th Cir. 1991) (citations omitted). The test is set forth repeatedly in Eighth Circuit cases. See Precision Constr. Co. v. J.A. Slattery Co., 765 F.2d 114, 118 (8th Cir. 1985) ("For twenty years the 'minimum contacts' requirement in this circuit has been tested against the five factors . ..." . .

95. See, e.g., Morris v. Barkbuster, Inc., 923 F.2d 1277, 1280-81 (8th Cir. 1991) (discussing the distinction betwcen claims arising out of defendant's activities within the forum state and those claims that do not relate to dcfendant's forum state activitics). 
been suggested that the lack of agreement regarding the personal jurisdiction rules is in part due to the disagreement regarding these pohicies. ${ }^{96}$ Accordingly, this Part discusses the most important policies behind personal jurisdiction. This Part argues that the disagreements over personal jurisdiction rules do not arise from policy disagreements. ${ }^{97}$ Ratlier, they arise because the agreed-upon policies are so general that they do not point to any specific rules.

\section{A. Cost Allocation Between Plaintiffs and Defendants}

First and foremost, personal jurisdiction serves to allocate the costs of litigation between the plaimtiff and the defendant. Given a choice, plaintiffs will usually pick the forum that is best for their own interests. For example, a party may favor a particular forum because it reduces its quantifiable litigation costs, such as travel and billable hours, or because the forum has favorable intrinsic characteristics, such as choice of law or jury pool demographics. ${ }^{98}$ Conversely, any restrictions on plaintiffs' ability to select a forum will, by definition, force some plaintiffs to give up their optimum forum. Such restrictions are basically a transfer of wealth froin plaintiffs to defendants.

Kulko v. Superior Court ${ }^{99}$ exemplifies how personal jurisdiction can anount to resolving an irreconcilable opposition of interests between plaintiffs and defendants. In Kulko, a divorced father hiving in New York consented to his child's moving to California to hive with the child's mother. In a suit to redetermine child support obligations, the Supreme Court lield that Cahfornia could not exercise personal jurisdiction over the father based upon that consent alone. ${ }^{100}$ Since the father agreed to the move in the child's interest and not in order to obtain a personal benefit, the Court's decision can be justified doctrinally under the purposeful availment test. Nonetheless, the decision remains fundamentally an allocation of litigation costs to the new custodial parent. Regardless of its doctrinal justification, many people would find that allocation unfair, simce the new custodial parent, precisely because of the burden of taking care of the child, is likely to be less prepared to cope with those additional hitigation costs.

96. Wendy C. Perdue, Personal Jurisdiction and the Beetle in the Box, 32 B.C. L. Rev. 529, 53033 (1991).

97. The policies discussed here are all widely, though not universally, accepted. Occasionally commentators write articles suggesting that personal jurisdiction be analyzed in light of a single overarching policy objective. See, e.g., Russell J. Weintraub, Due Process Limitations on the Personal Jurisdiction of State Courts: Time for Change, 63 OR. L. REv. 485, 522 (1984) (arguing for "fairness to the defendant under all circumstances"). But no single objective, even considered in isolation, leads to any definite rules.

98. For a discussion of lawyers' reasons for preferring one forum to another, see Edward A. Purcell, Jr., Geography as a Litigation Weapon: Consumers, Forum-Selection Clauses, and the Rehnquist Court, 40 UCLA L. REv. 423, $451-54$ (1992).

99. 436 U.S. 84 (1978).

100. Id. at 101 . 
If one views litigants as simply plaintiffs or defendants, it is quite difficult to develop policy imtuitions about how to draw the lines between their interests. The only coherent policy imtuition one can identify is that some reasons for picking a forum are legitimate, while others amount to "forum shopping." It would be difficult, however, to construct a theory in which personal jurisdiction does not exist if the plamtiff has engaged in "forum shopping" because proving the plamtiff's imtent is difficult and, more importantly, no real consensus exists on what is illegitimate.

This lack of consensus as to what actions are legitimate and which are not is reflected in the Supreme Court's ambivalence towards choice of law in forum non conveniens and $\S 1404$ (a) transfer. ${ }^{101}$ On the one hand, courts deciding forum non convemiens motions are not supposed to give substantial weight to choice of law, ${ }^{102}$ suggesting that a change in substantive law is not a legitimate reason for picking a forum. On the other hand, plaintiffs in $\S 1404$ (a) transfers maintain their original choice of law, ${ }^{103}$ suggesting that choice of law is such a legitimate reason for picking a forum that plaintiffs should not lose that advantage even when they seek the $\S$ 1404(a) transfer themselves. ${ }^{104}$

One might argue that the most obvious and egregious cases of forum shopping should at least form the basis for limitations on personal jurisdiction. For example, a plaintiff should seemingly not be able to choose a forum that is highly inconvenient to both her and the defendant, when the sole purpose is to impose greater costs on the defendant. Yet, it is not clear that such egregious behavior is universally viewed as wrongful. ${ }^{105}$ After all, other procedural practices, such as discovery, allow litigants to strategically impose costs on other parties, and such practices appear to be widely accepted. ${ }^{106}$

101. "For the convenience of parties and witnesses, in the interest of justice, a district court may transfer any civil action to any other district or division where it might have been brought." 28 U.S.C. $\S 1404$ (a) (1988).

102. Piper Aircraft Co. v. Reyno, 454 U.S. 235, 247 (1981).

103. Ferens v. John Deere Co., 494 U.S. 516, 523 (1990).

104. Regarding forum shopping, see also Louise Weinberg, Against Comity, 80 Geo. L.J. 53, 6869 (1991), arguing that we now have what amoants to a "fonum shopping system." The legitimacy of jury pool demographics as a choice of forum consideration is also debatable. For instance, a number of commentators have recently advocated limiting changes of venue in criminal cases on the basis of jury pool demographics. See, e.g., Note, Out of the Frying Pan or Into the Fire? Race and Choice of Venue After Rodney King, 106 HaRv. L. REv. 705, 708 (1993).

105. For example, Professor Purcell recently published a scathing attack on forum selection clauses in contracts. Purcell, supra note 98 . In his view, such clauscs are a "method whereby companies multiply the transaction costs that litigation imposes on those with claims against them in order to force such claimants to discount or abandon their claims." Id. at 455 . He nonetheless argued that as long as courts uphold such clauses, "corporate attorneys certainly have the right, and probably the professional ethical duty, to inform their clients of the advantages such clauses offer and to urge them to seize the opportunity presented." Id. at 459 (emphasis added).

106. For a discussion of the propriety of using discovery to impose costs on the adversary, see Jeffrey J. Mayer, Prescribing Cooperation: The Mandatory Pretrial Disclosure Requirement of Proposed Rules 26 and 37 of the Federal Rules of Civil Procedure, 12 REv. Lmo. 77, 102 (1992) ("An 
In conclusion, cost allocation between plaintiffs and defendants is greatly affected by personal jurisdiction rules, but this impact provides little guidance in determining what those personal jurisdiction rules should be.

\section{B. Proportionality and Nonaffiliation}

One principle that is helpful in understanding relatedness rules is proportionality between in-forum economic activity and litigation. For example, if a busmess operates in several states, it seems desirable that any litigation resulting from the business' conduct be spread among the states in rough proportion to the amount of business transacted. Conversely, it appears undesirable for litigation to be bunched in one "magnet forum"107 because that forum offers some favorable characteristic such as a particularly pro-plaintiff law. An example of such bunching is the concentration of oil lease lawsuits in Kansas exemplified by Phillips Petroleum Co. v. Shutts. ${ }^{108}$

Bunching can defeat a defendant's expectations and make its planning harder. The defendant's potential surprise at being subject to an unusually unfavorable substantive legal rule in one state is multiplied if litigation bunches in that state and the rule also comes to govern transactions entered into in other states.

What is more, bunching, at least when motivated by choice of law concerns, frustrates the policy objectives of the states where the litigation is not taking place. Those states, presumably for a reason, have adopted a more pro-defendant rule, which is being denied effect. In extreme cases, the other states' rules can become a nullity because everyone will select the favorable forum. ${ }^{109}$ Bunching also can be seen as an information loss to the country as a whole, in that states partially lose the ability to experiment with different kinds of rules. ${ }^{110}$

attomey refusing to put pressure on an opponent through discovery, knowing that it would advance his elient's interests and knowing as well that the courts would not punish the exertion of that pressure, arguably is violating his client obligations.').

107. For a discussion of "magnet forums," see Arthur R. Miller \& David Crump, Jurisdiction and Choice of Law in Multistate Class Actions After Phillips Petroleum Co. v. Shutts, 96 YALE L.J. 1, 57-59 (1986).

108. 472 U.S. 797,815 (1985) (" $[$ S $]$ ome $97 \%$ of the plaintiffs in the case had no apparent connection to the State of Kansas except for this lawsuit."). In Phillips Petroleum, the Supreme Court deprived plaintiffs of one advantage of bunching by holding that Kansas could not always apply its own law. Id. at 818. However, plaintiffs in a similar case were permitted to gain certain advantages by retaining their choice of forum. See Sun Oil Co. v. Wortman, 486 U.S. 717, 728-34 (1988).

109. An example of this is how pro-shareholder state corporation laws are partially nullified because any large corporation can afford to incorporate in Delaware, where the corporation laws are management-friendly. "The more protective Delaware becomes of corporate managements, the more difficult it becomes for other states to encourage high standards of corporate fiduciary behavior and shareholder protection." William S. Lerach, Securities Class Actions and Derivative Litigation Involving Public Companies: One Plaintiff's Perspective, in Securrtes LITIGATION 1990, at 65, 206 (PLI Litig. \& Admin. Practice Course Handbook Series No. 399, 1990).

110. 
A second principle that justifies personal jurisdiction rules is nonaffiliation. Nonaffiliation is the notion that a business, or for that matter an individual, should have a clear way of avoiding a particular state's laws. This principle is socially desirable, for example, so that states which adopt rules inaking it inore costly to operate certain kinds of businesses will feel the consequences of businesses leaving the state. Nonaffiliation can be expensive - it inay require refusing to enter into lucrative deals with state residents - but it should reinain an option. ${ }^{111}$ This is especially important for foreigners who need a clear way to structure operations in order to avoid, for example, private lawsuits under American securities and antitrust laws. ${ }^{112}$

World-Wide Volkswagen Corp. v. Woodson ${ }^{113}$ nicely illustrates the problein of nonaffiliation. The plaintiffs had an accident in Oklahoma with a car they had purchased in New York. They brought suit in Oklahoina against the auto dealer. ${ }^{114}$ If they had obtained jurisdiction over the dealer in Oklahonia simply because they had driven the car there, then every auto dealer would have been subject to nationwide jurisdiction, since cars sold in one state can foreseeably get into accidents in any other state. In other words, auto dealers would have lost the right of nonaffiliation. Nonaffiliation niay at least partially explain the Suprenie Court's unwillingness to find jurisdiction over the dealer. ${ }^{115}$

Proportionality and nonaffiliation are problemnatic as guides to action because they only require that outcomes be constrained within a very broad range. Thus, only egregious bunching threatens the systenı's interest in letting states have laws which are inore pro-defendant than their neighbors'. Only a rare harsh exercise of extraterritorial jurisdiction will completely take away a class of persons' ability to nonaffiliate. Because these policies ask only for loose restraints, they give little guidance for devising specific

It is one of the happy incidents of the federal system that a single courageous State may, if its citizens choose, serve as a laboratory; and try novel social and economic experiments without risk to the rest of the country. This Court has the power to prevent an experiment. We may strike down the statute which embodies it on the ground that, in our opinion, the measure is arbitrary, capricious or unreasonable. We have power to do this ... [b]ut in the exercise of this high power, we must be ever on our guard, lest we erect our prejudices into legal principles.

New State Ice Co. v. Liebmann, 285 U.S. 262, 311 (1932) (Brandeis, J., dissenting).

111. See Stewart, supra note 61, at 19 (describing nonaffiliation as "basic to our govemmental structure"). An extension of this principle is that if one operates several lines of business, one should be able to limit some of them to certain states even though one pursues others in different states-what one might call partial nonaffiliation. Id. at 25-26 (discussing partial nonaffiliation).

112. Cf. Consolidated Gold Fields PLC v. Minorco, S.A., 871 F.2d 252, 262-63 (2d Cir.) (finding that a British tender offer became subject to American law because offering documents were forwarded to Britisl nominees of American shareholders), cert. dismissed, 492 U.S. 939 (1989).

113. 444 U.S. $286(1980)$.

114. Id. at 288.

115. See id. at 296 ("Every seller of chattels would in effect appoint the chattel his agent for service of process. His amenability to suit would travel with the chattel."). 
jurisdictional rules, save that those rules need not constrain personal jurisdiction very much.

\section{Consent/Exchange}

Another widely discussed justification for personal jurisdiction is consent. ${ }^{116}$ The basic idea is that, by doing the things defined as purposeful availment, the individual or business "consents" to jurisdiction. A closely related notion is the "exchange theory," which implies consent under the notion that one receives benefits by acting in the forum in exchange for the burden of being subject to litigation there. Such benefits conferred by the forum include, for example, police protection and the use of state highways.

Although the consent/exchange theory has both intuitive appeal and good support in Supreme Court cases, ${ }^{117}$ it fails to help one arrive at any particular jurisdictional rules because there is no extrinsic way of identifying what kind of hitigation burden is a fair exchange for the benefits received. Furthermore, courts will have difficulty determining the kinds of acts for which states may legitimately infer consent to jurisdiction. ${ }^{118}$ Lacking what Professor Perdue has called "a meta theory of legitimacy," 119 the consent/exchange theory amounts to little more than one's intuitions regarding fairness-intuitions which differ widely among individuals. For example, Justice Scalia in Burnham v. Superior Court ${ }^{120}$ described as unconscionable the same exchange which Justice Brennan found eminently fair. ${ }^{121}$ For Justice Scalia, the benefits a defendant receives from a very short visit to a state are not a fair exchange for the burden of jurisdiction. ${ }^{122}$ On the other hand, for Justice Brennan fair exchange means little inore than

116. The consent approach is surveyed and criticized in Perdue, supra note 96, at 536-46, and in Allan R. Stein, Styles of Argument and Interstate Federalism in the Law of Personal Jurisdiction, 65 TEx. L. REV. 689, 724-32 (1987).

117. See Stein, supra note 116, at 724 (speaking of the "dominance of the exchange justification" in the Supreme Court's recent cases). The fair exchange theory was powerfully advocated by Justice Brennan in Burnham v. Superior Court, 495 U.S. 604, 637-38 (1990) (Brennan, J., concurring) (joined by Blackmun, Marshall \& O'Connor, JJ.). Judge Posner also likes the exchange idea: “Personal jurisdiction over nonresidents of a state is a quid for a quo that consists of the state's extending protection or other services to the nonresident . ..." Coté v. Wadel, 796 F.2d 981, 984 (7th Cir. 1986).

118. There are certain kinds of defamation cases where courts often find personal jurisdiction but the fair exchange theory cannot justify it. Suppose you get a phone call asking for an employment reference, give a negative one, and get sued for defamation on the basis of what you said. In what sense have you received any benefit from the caller's state? You may not even know which state it was if the caller did not identify it. Cf. Brainerd v. Governors of the Univ. of Alta., 873 F.2d 1257, 1259 (9th Cir. 1989) (finding personal jurisdiction for defamation on the basis of a long-distance employment reference); see also Perdue, supra note 96, at 541 (arguing that one defendant in Calder v. Jones, 465 U.S. 783 (1984), received no "meaningful benefits" from the fonum, "at least none beyond those received by all employees of corporations doing business" there).

119. Perdue, supra note 96 , at 542. In other words, Perdue argues that we need some theory independent of consent to justify the rules for inferring consent. Id.

120. 495 U.S. 604 (1990).

121. Id. at 623 (Scahia, J.), 637-39 (Brennan, J.).

122. Id. at 623 (Scalia, J.). 
an implementation of the nonaffiliation concept dcscribed in the previous section, whereby jurisdiction will not lie over those who have totally avoided the forum. ${ }^{123}$

The consent/exchange theory sheds particularly little light on what the appropriate relatedness test should be. In fact, this theory inerely demands that the magnitude of the litigation burden inposed by the forum not greatly outweigh the benefits received by the defendant from in-forum activity. Under this theory, relatedness is only one possible mechanism, and is by no means a necessary one, for keeping the litigation burden in line with the benefits.

\section{Backstopping Choice of Law, \& 1404(a) Transfer, and Forum Non Conveniens}

Although it may seem paradoxical, one of the major roles personal jurisdiction plays in American law is a backstop ${ }^{124}$ for choice of law. This happens because American courts have a strong tendency to apply the law of the forum. ${ }^{125}$ There is, however, a constitutional constraint that the state whose law is chosen must have a "significant contact or significant aggregation of contacts" with the cause of action. ${ }^{126}$ When jurisdiction is obtamed under the specific jurisdiction test, the contacts that justify jurisdiction will also serve to meet this test, and thus it will be constitutional to apply the law of the forum. ${ }^{127}$ Personal jurisdiction thus prevents courts from reaching the choice of law question in a number of cases where it would be incorrect for them to do what comes naturally and apply forum law.

Commentators have viewed this backstop function favorably. Professor Perdue, in her recent comprehensive study of the policies behind personal jurisdiction, wrote that "the most likely basis for any significant personal jurisdiction limitation is choice of law."128 Professor Weintraub, advocating a jurisdiction doctrine based on "fairness to the defendant under all circumstances," 129 believes that "[p]erhaps the most important element of forum unfairness to [the] defendant involves choice of law."130

123. See id. at $637-38$ (Brennan, J.).

124. Personal jurisdiction backstops for a legal rule when a case where that other rule would ordinarily have to be applied can be dismissed first on personal jurisdiction grounds without getting to the other rule.

125. See generally Roger C. Cramton et al., Conflict of Laws 308-13, 319-30 (4th ed. 1987) (discussing the law of the forum and "better law" approaches).

126. Phillips Petroleum Co. v. Shutts, 472 U.S. 797, 818 (1985) (quoting Allstate Ins. Co. v. Hague, 449 U.S. 302, 312-13 (1981) (plurahity opinion)).

127. Earl M. Maltz, Visions of Fairmess-The Relationship Between Jurisdiction and Choice-ofLaw, 30 ARzz. L. Rev. 751, 760-61 (1988); see also Perdue, supra note 96, at 571 (arguing that personal jurisdiction could keep cases out of states that would not be permitted to apply their own law).

128. Perdue, supra note 96 , at $562,570-73$.

129. Weintraub, supra note 97 , at 522 .

130. Id. at 524 . 
Personal jurisdiction's backstopping effect on choice of law limits state sovereignty by not allowing a state to make laws that will bind individuals who are not subject to personal jurisdiction in the state. In this way, the backstopping supports the proportionality and nonaffiliation policies described earlier. ${ }^{131}$

Personal jurisdiction also serves as a backstop for forum non conveniens and $\S 1404$ (a) transfer ${ }^{132}$ motions in federal courts, because courts are able to dismiss cases based on lack of jurisdiction before ever reaching those issues. Among other benefits, this helps make outcomes more predictable. Muddy as the law of personal jurisdiction is, the personal jurisdiction test is still more concrete than the other doctrines because there are many cases in which related contacts clearly do not exist and the unrelated contacts are too few to satisfy general jurisdiction. In comparison, forum non conveniens and $\S 1404$ (a) transfers are decided by means of tests that always balance a number of factors. ${ }^{133}$

Again, the backstopping function is important in practice and widely recognized as desirable, but it does not lead to any specific personal jurisdiction rules. At best backstopping suggests that personal jurisdiction should contain a rough approximation of the rules of the other doctrines for which it is backstopping. ${ }^{134}$

\section{E. Interstate Federalism and Due Process}

Commentators have set forth a number of other potential policy justifications for personal jurisdiction. ${ }^{135}$ These include, notably, different versions of interstate federalism and due process. ${ }^{136}$ However, like the previous policy justifications, these policies provide little guidance in resolving questions surrounding the meaning of "relatedness."

Personal jurisdiction certainly has something to do with the limits on state sovereignty. So does the dormant commerce clause, which limits state regulation of interstate commerce. ${ }^{137}$ But just as it is very difficult to say what standards should be applied under dormant commerce clause analy-

131. See supra Section II.B.

132. See supra note 101 .

133. Piper Aircraft Co. v. Reyno, 454 U.S. 235, 241 \& n.6 (1981) (listing factors to be balaneed in a forum non conveniens analysis). The balancing test for a $§ 1404$ (a) transfer is so open-ended that the courts have not even attempted to list all the relevant factors. 15 CHARLES A. WrIGHT ET AL., FederAL Practice and Procedure § 3847, at 368-69 (2d ed. 1986).

134. This is a major conclusion of Professor Perdue's study. Perdue, supra note 96, at 572 ("Personal jurisdiction can be treated as simply a first cut at dealing with choice of law problems and an admittedly imperfect one.'). The reasonableness fork of specific jurisdiction is already quite close to forum non conveniens. Compare supra text accompanying note 85 (First Circuit's reasonableness test) with Piper Aircraft Co., 454 U.S. at 241 n.6 (Supreme Court's forum non conveniens test).

135. See generally Perdue, supra note 96 (surveying the field).

136. See Stein, supra note 116, at 738 (advocating jurisdiction only over cases where a state has a regulatory interest).

137. See U.S. CoNST. art. I, \& 8, cl. 3. 
sis, ${ }^{138}$ so too sovereignty-derived arguments lead to no clear conclusion regarding personal jurisdiction. Certainly, state sovereignty should be limited in soine respects. However, other than obvious cases like two states applying incoinpatible rules to the same conduct, ${ }^{139}$ there is little further agreement on the appropriate limits.

Personal jurisdiction doctrine is a formal consequence of the Due Process Clause of the Fourteenth Amendment. ${ }^{140}$ One could imagine, then, that general due process doctrine would shed light on an appropriate personal jurisdiction test. A few commentators, notably Professor Redish, ${ }^{141}$ have tried to establish this link between due process and personal jurisdiction, but there are considerable difficulties. For example, assuming personal jurisdiction to be an aspect of procedural due process, ${ }^{142}$ one would expect it to bear some relation to the Mathews $v$. Eldridge ${ }^{143}$ balancing test. The Mathews test is "something akin to a general formula for the determination of what process is due," ${ }^{, 144}$ and requires the balancing of three factors:

[F]irst, the private interest that will be affected by the official action; second, the risk of an erroneous deprivation of such interest through the procedures used, and the probable value, if any, of additional or substitute procedural safeguards; and finally, the Government's interest, including the function involved and the fiscal and administrative burdens that the additional or substitute procedural requireinent would entail. ${ }^{145}$

Consider briefly how these factors might apply to personal jurisdiction. The first Mathews factor, the private interest affected, will vary according to the precise subject of the lawsuit. It would seem to require different personal jurisdiction standards for different causes of action, or at least for different kinds of relief.

138. Tyler Pipe Indus., Inc. v. Washington State Dep't of Revenue, 483 U.S. 232, 259-60 (1987) (Scalia, J., dissenting) (advocating an end to the expansion of dormant commerce clause doctrine).

139. An example of this is Bibb v. Navajo Freight Lines, 359 U.S. 520, 522-23 (1959), where Illinois required trucks using its highways to have curved mudflaps while Arkansas forbade them. As a result, a truck could not be driven from Illinois to Arkansas without changing mudflaps. Judicial invalidation of conflicting state restrictions that are less direct has been much more controversial, as in Kassel v. Consolidated Freightways, 450 U.S. 662 (1981), where the Court split 4-2-3. In Kassel, the Court found an Iowa statute prohibiting the use of 65 -foot double-trailer trucks within its borders unconstitutional where all other states in the Midwest allowed them.

140. See, e.g., International Shoe Co. v. Washington, 326 U.S. 310, 316 (1945) ("DD]ue process requires ... minimum contacts ....").

141. Martin H. Redish, Due Process, Federalism, and Personal Jurisdiction: A Theoretlcal Evaluation, $75 \mathrm{Nw}$. U. L. Rev. 1112, 1114 (1981).

142. There is some disputc as to whether personal jurisdiction should be classified as procedural or substantive due process. See Wendy C. Perdue, Sin, Scandal, and Substantive Due Process: Personal Jurisdiction and Pennoyer Reconsidered, 62 WASH. L. REv: 479, 508-09 (1987) (arguing that the proper classification is substantive, but recognizing that some commentators see it as procedural).

143. 424 U.S. 319 (1976).

144. Laurence H. Tribe, American Constitutional Law § 10-13, at 715 (2d ed. 1988).

145. Mathews, 424 U.S. at 335. 
The second Mathews factor, the "risk of an erroneous deprivation," will vary according to the degree to which forum inconvenience inakes it difficult for the plaintiff or defendant to inount an effective case. ${ }^{146}$ Application of this factor would also vary according to: (1) whether the foruun is applying its own law; with which it is familiar, or the less familiar law of another state or a foreign country; (2) whether certain witnesses can be required to appear for trial in one forum but not in another; and (3) whether judges or juries in the forum are biased against outsiders. ${ }^{147}$

"Government interest," the final factor, could reflect the justice system's interest in efficient resolution of the lawsuit, if narrowly interpreted. This would appear to favor, for example, a court familiar with the law to be applied, or a court where related cases could consolidate. If interpreted broadly to reflect the forum's interest in inaintaining justice, this factor would again seein to favor the forum whose law is to be applied, or perhaps the plaintiff's hoine forum. ${ }^{148}$ In short, the personal jurisdiction doctrine that would follow from Mathews would certainly depend heavily upon the meaning attached to "government interest."

From the above analysis, one can conclude three things. First, a Mathews-derived personal jurisdiction test would balance a number of factors, thus leading to a rather indefinite test. Second, a balancing of those factors would probably vary according to the subject matter of the lawsuit. Third, the court's balancing would not focus on the defendant's contacts in the sanie way that the present test does; indeed, consideration of the defendant's contacts does not seein to fit into a Mathews-derived analysis at all. In sum, although Mathews might lead to a wholly new balancing test for personal jurisdiction, it provides little guidance in resolving the difficult questions about "relatedness" that arise within the present prevailing test.

146. Professor Redish agrees that this type of inconvenience should be an important consideration in a personal jurisdiction version of a due process analysis. See Redish, supra note 141, at 1138 ("[A]n initial hurdle for a finding of unconstitutionality is a finding of meaningful inconvenience.").

147. Professor Redish argues that bias of this sort sliould not be taken into account for due process purposes, at least in part because diversity jurisdiction is supposed to take care of those problems. Id. at 1139.

148. Professor Redish views the state's interest in having its own law applied as the primary state interest to be considered. See id. at 1139-41. The Supreme Court, in applying the Mathews test, has been willing to consider a number of different kinds of state interests. See, e.g., Dixon v. Love, 431 U.S. 105, 114 (1977) (considering the "public interest in safety on the roads and highways, and in the prompt removal of a safety hazard"); Hortonville Joint Sch. Dist. No. 1 v. Hortonville Educ. Ass'n, 426 U.S. 482, 495 (1976) (contemplating the "interests of the school system, the interests of the parents and children who depend on the system, and the interests of the citizens whose taxes support it"). 
III

\section{The "But For" Test and Its Problems}

\section{A. "But For" in the Courts}

The Ninth Circuit adopted "but for" causation as its test of relatedness in Shute v. Carnival Cruise Lines. ${ }^{149}$ The test provides that in determining whether a forum can exercise personal jurisdiction over a defendant, the contact in question inust be a "but for" cause of the plaintiff's injury. In applying the test, the court found personal jurisdiction over a cruise ship coinpany in a suit brought by a passenger who slipped and fell during a cruise. The defendant had advertised in the forum and the plaintiffs had reserved their place on the cruise with a nonrefundable payment inailed froin the forum. ${ }^{150}$ The Ninth Circuit concluded that "but for" the cruise line's advertisennents in the forum, the plaintiff would not have been on the cruise and would not have suffered the injury. ${ }^{151}$

The "but for" test has also found favor with other federal courts of appeal. The Sixth Circuit, for example, referred to "but for" causation in a case where the plamtiff responded to an advertiseinent, becaine a patient at the defendant inedical center, and later brought a medical inalpractice claim. ${ }^{152}$ In another Sixth Circuit case, the court appeared to apply the "but for" test by using arguably synonymous "made possible by" language. ${ }^{153}$ The court in that case found sex discrimination in the administration of a dental certification exam to "arise out of" the plaintiff's contract to take the exam. ${ }^{154}$ Thus, it appears from the above cases that the Sixth Circuit considers the "but for" test to be one acceptable way of proving relatedness. However, there are indications that the Sixth Circuit may view the "but for" test as too narrow in other cases. ${ }^{155}$

The Seventh Circuit in Deluxe Ice Cream Co. v. R.C.H. Tool Corp. ${ }^{156}$ found personal jurisdiction over an out-of-state defendant based on an instate meeting with another defendant concerumg the solicitation of the con-

149. 897 F.2d 377, 385 (9th Cir. 1990), rev'd on other grounds, 499 U.S. 585 (1991).

150. Id. at 379.

151. Id. at 386.

152. Creech v. Roberts, 908 F.2d 75, 80 (6th Cir. 1990) ("If the 'Expect a Miracle' program had not been televised in Ohio, Creech would never have become interested in seeking healing at the Center, would never have seen the phone number to call to make an appointment at the Center, and would never lave undergone surgery at the Center.') (named defendant was televangelist Oral Roberts, who settled), cert. denied, 499 U.S. 975 (1991).

153. Lanier v. American Bd. of Endodontics, 843 F.2d 901, 909 (6th Cir.), cert. denied, 488 U.S. 926 (1988). Contrast this with Burstein v. State Bar, 693 F.2d 5II, 523 (5th Cir. 1982), where the Fifth Circuit held that a contract to take an out-of-state bar examination did not confer personal jurisdiction over the bar examiners on a $\$ 1983$ claim. The court first expressed doubt that the contract was even formed while the plaintiff was in the forum, id. at 518 , and then concluded that the contract had no "substantial connection" with the forum, id. at 519.

154. Lanier, 843 F.2d at $908-09$.

155. See infra note 220.

156. 726 F.2d 1209 (7th Cir. 1984). 
tract that eventually gave rise to the dispute. ${ }^{157}$ Again, it appears that an expansive "but for" notion is at work; "but for" the preliminary discussions in the forum, the contract giving rise to the breach would not have resulted.

The Fifth Circuit's stance on the "but for" test is unclear. In Prejean $v$. Sonatrach, Inc., ${ }^{158}$ the plaintiff brought suit after her husband died in an accident while einployed as an oil worker abroad. ${ }^{159}$ Reversing and remanding the district court's dismissal for lack of personal jurisdiction, the Fifth Circuit held that if the einployment contract had been formed in Texas, the contract would be relevant to jurisdiction as a "but for" cause of the tort. ${ }^{160}$ More recently, the Fifth Circuit found personal jurisdiction in another personal injury case in which the defendant held meetings and recruited employees, including the plaintiff, froin the forum state. ${ }^{161}$

However, the Fifth Circuit reached the opposite outcome in Aviles $v$. Kunkle, ${ }^{162}$ where migrant farmworkers sued an Ohio employer in Texas for violations of federal statutes protecting farmworkers. ${ }^{163}$ The district court had found personal jurisdiction based on the employment contract formed by inail and telephone while the plaintiffs were in Texas. ${ }^{164}$ The Fifth Circuit reversed, holding that "plaintiffs' cause of action is not based upon any contract, tort, or recruitment in Texas, but upon the alleged violation of two federal statutes arising solely out of their einployment in Ohio."165

The First and Eighth Circuits have reached results clearly at odds with the "but for" test. A representative First Circuit case is Pizarro v. Hoteles Concorde International, ${ }^{166}$ where the court found that defendant's advertisements in a forum newspaper had no connection to the act that caused the injury, and were therefore insufficient to establish personal jurisdiction. ${ }^{167}$ Similarly, in the Eighth Circuit case Sybaritic, Inc. v. Interport International, Inc., ${ }^{168}$ the court found insufficient contracts to support jurisdiction. The plaintiff was a manufacturer of fitness equipinent and "relaxation products." 169 The defendant, an exporter, had approached the plaintiff and entered into negotiations, some in the forum, which culminated in the

I57. The court held that "the discussions that took place in Illinois between [the defendants] played a part in the subsequent negotiations between [the in-state defendant] and the plaintiff, which led to the contract." Id. at I215-16.

158. 652 F.2d 1260 (5th Cir. Unit A 1981).

159. Id. at 1264.

160. Id. at I $270 \mathrm{n} .2 \mathrm{I}$ ("In a case like this, the contractual contact is a "but for' causative factor for the tort since it brought the parties within tortious 'striking distance' of each other.").

161. Coats v. Penrod Drilling Corp., 5 F.3d 877, 883-84 (5th Cir. 1993).

162. 978 F.2d 201 (5th Cir. 1992) (per curiam).

163. Id. at 203.

164. Id. at $204 \&$ n.4.

165. Id. at 205.

I66. 907 F.2d 1256 (1st Cir. 1990).

167. Id. at 1259.

168. 957 F.2d 522, 524-55 (8th Cir. 1992).

169. Id. at 523 . 
signing of a purported "Agency Agreement" between the parties. ${ }^{170}$ The suit sought a declaration that there was no agency relationship between the parties. ${ }^{171}$ In refusing to find jurisdiction, the Eighth Circuit dismissed the in-forum negotiations as "only preliminary." no final agreement without preliminary negotiations, this holding suggests the rejection of the "but for" test. ${ }^{173}$

\section{B. The Problems with "But For"}

\section{Multiple or Cumulative Injury}

The "but for" test runs into difficulties in cases where the injury is either inultiple or cumulative. An example of a multiple injury is defamation by publication, where the plaintiff technically suffers imjury each time someone reads the defamatory statement. In other words, the entire injury consists of a number of small subinjuries, and in a sense, none of the individual sales of the publication is a "but for" cause of the plaintiff's entire injury because the plaintiff would still be injured even if any one of those sales liad not taken place.

Recognizing the difficulties inherent in applying a "but for" causation test to inultiple injury cases, one district court held that in a patent infringement case, the "but for" test is "simply mapplicable" to multiple injury cases. ${ }^{174}$ The multiple injury problein is not, however, insurmountable. For instance, one can modify the test slightly and hold that where the injury is divisible into pieces, the contact is sufficient to establish personal jurisdiction if it is a "but for" cause of one of the pieces. Thus, even if the defendant sold just one copy of the defamatory publication in the forum, the court could exercise jurisdiction over the defendant because that contact is a "but for" cause of a part of the plaintiff's injury. ${ }^{175}$

Cumulative injury exists where effects accumulate slowly, eventually reaching a level that constitutes injury. This injury is sinilar to water dripping into a bucket until the bucket overflows. If just enough drops of water drip to make the bucket overflow, every single drop is necessary to that result, and thus eacli drop is a "but for" cause of the overflow. On the other hand, if more drops fall than are needed to cause overflow, then overflow

170. Id.

171. Id.

172. Id. at 525 .

173. There is an obvious contrast between the First and Eighth Circuits, and the Seventh Circuit in Deluxe Ice Cream, discussed supra notes 156-57 and accompanying text, where the court found an inforum meeting between co-parties to discuss how to solicit the contract at issue sufficient to establish jurisdiction.

174. Wilden Pump \& Eng'g Co. v. Versa-Matic Tool Inc., 20 U.S.P.Q.2d (BNA) 1788, 1790 (C.D. Cal. 1991).

175. See Keeton v. Hustler Magazine, Inc., 465 U.S. 770 (1984) (allowing an out-of-state defamation plaintiff to sue the magazine in New Hampshire, even though only a tiny fraction of the magazine's circulation went to that state). 
would occur even if any particular drop had not fallen, and thus arguably, none of the drops is a "but for" cause.

The cumulative injury problem is analogous to that raised by certain well-known examples of multiple causation in tort discussions of "but for" causation. Perhaps the best known example is when a "defendant sets a fire, which merges with a fire from some other source [and] the combined fires burn the plaintiff's property . ..."176 In tort law, several leading authorities have argued that this kind of example requires that another causal theory supplement the "but for" cause. For example, Dean Prosser recommends a "substantial factor" test. ${ }^{177}$ Applying this hine of analysis to the personal jurisdiction context, Prosser's theory would require a determination of whether the defendant's forum contacts were a "substantial factor" contributing to the plaintiff's imjury.

Another example of cumulative imjury appeared in a recent debate in the Harvard Law Review. ${ }^{178}$ Professors Hansmann and Kraakman had proposed that states pass laws obligating shareholders to pay the tort liabilities of insolvent corporations. ${ }^{179}$ Their prototypical examples were a Bhopallike release of a poisonous chemical cloud and an Exxon Valdez-style massive oil spill. ${ }^{180}$ Professor Alexander raised concerns about the states' abilities to gam personal jurisdiction over the shareholders. ${ }^{181}$ Assuming, as was done in the debate, that the tort took place in the forum, ${ }^{182}$ one must ask whether a shareholder's act of investing im the corporation is a forum contact related to the tort. For widely-held compamies at least, it would appear not to be a "but for" cause of the tort because one shareholder's additional investment would not make it possible for a corporation to spill oil or release a poison cloud. On the other hand, the total investinent of many shareholders in a corporation is arguably a cumulative cause of all of the corporation's activities. Applying Prosser's theory, courts could ask whether that individual shareholder's investinent was a "substantial factor" in making it possible for the corporation to commit the tort.

\section{Mismatch with Social Activities in the Causal Chain}

A further problem with "but for" causation is its mismatch with the social activities that are part of the causal cham in typical personal jurisdiction disputes. In tort causal chams, one usually encounters physical phe-

176. William L. Prosser, HandbooK of the LAw of TORTS 239 (4th ed. 1971).

177. Id. at 240. The difficulty of applying this test is suggested by Dean Prosser's recommendation that it be "for the jury to determine, unless the issue is so clear that reasonable men could not differ." Id.

178. Janet C. Alexander, Unlimited Shareholder Liability Through a Procedural Lens, 106 HARv. L. Rev. 387 (1992); Heury Hansmann \& Reinier Kraakman, A Procedural Focus on Unlimited Shareholder Liability, 106 HARv. L. REv. 446 (1992).

179. See Henry Hansmann \& Reinier Kraakman, Toward Unlimited Shareholder Liability for Corporate Torts, 100 Y ALE L.J. 1879, 1922 (1991).

180. Hansmann \& Kraakman, supra note 178 , at 448-49.

181. Alexander, supra note 178.

182. Id. at 396. 
nomena such as a speeding car, a careless shotgun blast, or a baby food spill on a supermarket floor. Conversely, contacts in personal jurisdiction cases are generally social acts, like advertising directed at forum residents. In the latter instance, the causal link between those acts and the injuries necessarily passes through some conscious decision on the plaintiff's part. One example is a plamtiff's conscious decision to buy an advertised product.

Where social phenomena are involved, "but for" causation can be difficult to prove. The facts of Shute provide a relatively simple example. In Shute, the causal link was between advertising and consumer decisions, arguably a tenuous one. Many people see an advertisement, but only a few buy the product. More significantly, people often buy a product without ever having seen it advertised. Nonetheless, the Ninth Circuit in Shute decided that Carnival Cruise Lines' advertising was a "but for" cause of the Shutes' decision to take the cruise. ${ }^{183}$ It is at least conceivable, however, that something else, such as word-of-mouth recommendation, was the critical factor in that decision.

A further problem with applying the "but for" test to social phenomena is the need to distinguish mere historical causation from true "but for" causation. Consider this scenario: a Califorman studies law at Harvard, returns to practice in Califorma, and is alleged to have committed malpractice there. One could argue that she should be subject to suit in Massachusetts on the ground that her Harvard years were a "but for" cause of her becoming a lawyer, and therefore, of the allcged malpractice. However, because she presumably could have studied law elsewhere, the Harvard years were a historical cause of the malpractice, but not really a "but for" cause. That is to say, her studies at Harvard were a link in a chain of events that led to a certain outcome, but that outcome could easily have occurred without such events.

The distinction between "but for" cause and historical cause becomes more complicated when the scenario is slightly altered. Suppose the defendant was a Califorma doctor rather than a lawyer, who was adinitted to just one medical school, located im Indiana, despite having mailed out many applications and attended some interviews. There is now a much stronger case for "but for" causation because without the Indiana contacts, there would be no medical degree and no malpractice. Should there be jurisdiction over the malpractice claim in Indiana?

These scenarios were constructed to illustrate extreine situations, but obviously there are intermediate situations where the historical cause/"but for" distinction is difficult to make. In Heil v. Morrison Knudsen Corp., ${ }^{184}$

183. The court held that "Carnival's solicitation of business in Washington attracted the Shutes (through their travel agent) to the Camival cruise." Shute v. Carnival Cruise Lines, 897 F.2d 377, 386 (9th Cir. 1990), rev'd on other grounds, 499 U.S. 585 (1991). No single act of solicitation was identified as a "but for" cause.

184. 863 F.2d 546 (7th Cir. 1988). 
Judge Posner appears to have recognized the need to exclude mere historical causation from the jurisdictional test. ${ }^{185}$ The plaintiff sued various corporate officers for breach of their duties to the corporation. The alleged breach was the use of a poison pill to keep the plaintiff from taking over the company. Personal jurisdiction over the defendants in Illinois was predicated on the fact that they had adopted the poison pill at a meeting at O'Hare Airport. ${ }^{186}$ However, that meeting took place before the plaintiff became a shareholder. Judge Posner found no jurisdiction, observing that "[h]ad no poison pill been adopted [at O'Hare], the board would in all likelihood have adopted a poison pill in 1988 to stop Heil."187 In other words, the O'Hare meeting was a historical cause but not a true "but for" cause.

The Supreme Court was faced with another historical cause contact in Kulko v. Superior Court, ${ }^{188}$ which involved a defendant who was married during a brief visit to the forum. ${ }^{189}$ Although the marriage was a historical cause of the child support dispute, the Court held that the contact could not, by itself, support an exercise of jurisdiction over the defendant. ${ }^{190}$ One can thus read Kulko as a rejection of mere historical causation.

\section{Overly Remote Causes}

The "but for" test also accepts certain contacts that appear too remote from the cause of action to support an exercise of jurisdiction. Consider, for example, two Ninth Circuit cases cited in Shute: Thos. P. Gonzalez Corp. v. Consejo Nacional de Produccion ${ }^{191}$ and Scott v. Breeland. ${ }^{192}$ In both cases, the "but for" test would have found the contacts to be related, but the Ninth Circuit reached the opposite result.

In Thos. P. Gonzalez, the defendant and plaintiff had entered into a series of contracts. The suit concerned the last one, which was made and performed entirely outside the forum. Two of the earlier contracts, however, had been executed in the forum. ${ }^{193}$ It can be argued that in an ongoing business relationship of that type, each contract is a "but for" cause of the succeeding one. Nonetheless, the Ninth Circuit refused to consider the earlier contracts in deciding the existence of personal jurisdiction. ${ }^{194}$

185. Id. at $549-50$.

186. Id. at 547 .

187. Id. at 550. However, Heil was decided under the Illinois long-arm statute. At that time, the statute did not stretch to the full limits of federal constitutional due process. Deluxe Ice Cream Co.v. R.C.H. Tool Corp., 726 F.2d 1209, 1214 (7th Cir. 1984). Thus, the Seventh Circuit may still consider a broader form of the "but for" test acceptable in other states whose long-arm statutes are more expansive.

188. 436 U.S. 84 (1978).

189. Id. at 93.

190. Id.

19I. 614 F.2d 1247 (9th Cir. 1980).

192. 792 F.2d 925 (9th Cir. 1980).

193. Thos. P. Gonzalez, 614 F.2d at 1249.

194. See id. at 1254 ("We find the crucial fact to be that this visit pertained only to transactions not at issue in this case.'). 
In Scott v. Breeland, the defendants were a musician and his band who were on a plane in Nevada waiting to take off for California. The plaintiff was a flight attendant who claimed that the musician assaulted her while the plane was on the ground. ${ }^{195}$ But for the trip to California, they would not have been on that particular plane and that particular flight attendant would not have been assaulted. The Nimth Circuit nonethelcss held that the fact of gomg to California was unrelated to the cause of action. ${ }^{196}$

Other courts might have decided Scott differently. The California Supreme Court, for example, found personal jurisdiction over a truck driver involved in an accident on his way to California. ${ }^{197}$ Nonetheless, particularly long causal chains like that in Thos. P. Gonzalez seem to trouble the courts. As the chain stretches back in time, courts are likely to find that, at some point, the contacts occurred too long ago to be related.

\section{Jurisdiction Over Parent Corporations}

As a special case of overly remote contacts, consider the situation where the plaintiff has been injured by a subsidiary corporation and wishes to obtain jurisdiction over its corporate parent. If the parent formed the subsidiary in the forum, the forniation is arguably a "but for" cause of any of the subsidiary's activities. ${ }^{198}$ Thus, under the "but for" test, a court could exercise personal jurisdiction over the parent for any causes of action arising froin the subsidiary's activities. However, such a result is wholly at odds with the current rules regarding parent-subsidiary relations in personal jurisdiction. Courts currently presume that the subsidiary's contacts should not be attributed to the parent, unless the parent has exercised a great deal of control over the subsidiary. ${ }^{199}$

195. Scott, 792 F.2d at 926.

196. Id. at 928. In a similar case, the Seventh Circuit found no personal jurisdiction over a defendant who was involved in an auto accident as he returned from a visit to the forum. Saylor $v$. Dyniewski, 836 F.2d 341, 344 (7th Cir. 1988).

197. Cometison v. Chaney, 545 P.2d 264, 269 (Cal. 1976). In Cornelison, the defendant was delivering goods to California and intended to rcceive merchandise there for delivery elsewhere. $I d$. at 267-68. Because the trip was for a business purpose, the defendant's contacts almost certainly met the purposeful availment fork of the prevailing test. In contrast, in Scott, the defendant's trip to Califomia was neither related nor purposeful availment. 792 F.2d at 928.

198. In line with the discussion of historical cause in the preceding subsection, it could be argued that the parent corporation was determined to act in the forum and would have done so regardless of whether the subsidiary was formed there or in a different state.

199. See, e.g., United Elec. Workers v. 163 Pleasant St. Corp., 960 F.2d 1080, 1091, 1094 (1st Cir. 1992) (refusing to attribute subsidiary's contacts to parent). Different courts have different standards regarding the degree of control necessary to 'pierce the veil" and attrihute the subsidiary's contacts to the parent. See Lea Brilmayer \& Kathleen Paisley, Personal Jurisdiction and Substantive Legal Relations: Corporations, Conspiracies, and Agency, 74 CALIF. L. REv. 1, 28-32 (1986) (discussing cases that have applied different standards to various parent-subsidiary relationships). 


\section{Products Liability Cases Involving Out-of-Forum Purchases}

In products liability cases, plaintiffs have sometimes purchased the defective product outside the forum. If the manufacturer sells that saine product in the forum, one could argue that a court within the forum should still be able to exercise jurisdiction over the seller. Under the "but for" test, however, the forum could not exercise jurisdiction over the manufacturer because the sale of the product is not causally related to the plaintiff's purchase.

For example, in Seymour v. Parke, Davis \& Co., ${ }^{200}$ the First Circuit found no jurisdiction over a drug manufacturer in New Hainpshire, even though the manufacturer sold the defective product there. ${ }^{201}$ Similarly, in Bearry v. Beech Aircraft Corp., ${ }^{202}$ the Fifth Circuit demed jurisdiction over an airplane manufacturer with many in-forum sales because the "plane was not designed or manufactured in Texas, had never been owned by a Texas resident, and had never been repaired in or serviced in Texas."203 Once again, the product was not purchased within the forum. ${ }^{204}$

Perhaps moved in part by sympathy for the unfortunate plamtiff, other courts have held the opposite. For example, in Lee v. Walworth Valve $\mathrm{Co}^{205}$ the Fourth Circuit allowed the widow of a chief petty officer killed by an allegedly defective valve to sue the manufacturer in South Carolina, even though the particular valve that killed him had not been sold there. ${ }^{206}$ The court mentioned the manufacturer's sales in South Carolima, but it also emphasized the state's interest in providing a forum, and noted that there was no "taimt of forum shopping" since the widow was a resident of South Carolima. ${ }^{207}$ Later Fourth Circuit decisions, however, have limited Lee, refusing to extend jurisdiction to out-of-state plaimtiffs. ${ }^{208}$

The Eleventh Circuit in Vermeulen v. Renault, U.S.A., Inc. ${ }^{209}$ recently allowed a car buyer to file a products liability suit in Georgia even though

200. 423 F.2d 584 (1st Cir. 1970).

201. Id. at 587. Plaintiff in the wrongful death action resided in Massachusetts, but was appointed executrix in New Hampshire solely for the purpose of bringing suit there. The drug was also purchased and ingested by the decedent in Massachusetts. Id. at 585 .

202. 818 F.2d 370 (5th Cir. 1987).

203. Id. at 373 .

204. Id. at 372 .

205. 482 F.2d 297 (4th Cir. 1973).

206. Id. at 298.

207. Id. at 299-300.

208. See, e.g., Nichols v. G.D. Searle \& Co., 991 F.2d 1195, 1199 n.3 (4th Cir. 1993).

209. 965 F.2d 1014 (I th Cir. 1992) (Vermeulen N), superseded, 985 F.2d 1534 (11th Cir. 1993) (Vermeulen II). Vermeulen I was superseded because the court had failed to take into account the fact that the defendant was owned by the French government. Vermeulen II, 985 F.2d at 1553 (Roney, J., concurring). The court in Vermeulen II held that when a suit is against a foreign government, a defendant's minimum contacts are determined by the defendant's relationship with the United States as a whole, not any particular state. Id. at 1545. Accordingly, bccause the car was purchased in the United States, the court no longer had to consider relatedness. 
she had bought the car in North Carolina. ${ }^{210}$ Unfortunately, the decision did not discuss relatedness at all. Instead, the court skipped directly to a lengthy analysis of purposeful availment. ${ }^{211}$ Similarly, in World-Wide Volkswagen, ${ }^{212}$ the owners of an allegedly defective car purchased in New York sued the inanufacturer in Oklahoma. ${ }^{213}$ The inanufacturer, unlike the regional distributor and the dealer, did not contest personal jurisdiction. However, the Supreme Court, in dictum, implied that such jurisdiction should exist because of the manufacturer's sales in the forum. ${ }^{214}$ Relatedness was not discussed.

\section{Purchase of an Instrumentality Used to Commit a Tort}

A further anomaly of the "but for" test arises in cases where a tort was committed by the negligent use of soine inechanical instrumentality, like a helicopter. Arguably, there would be no tort if the defendant had not purchased or used that instrumentality. Suppose the instrumentality was bought in the forum. This was the case, for exantple, in Helicopteros, where the helicopter that crashed was purchased in the forum. ${ }^{215}$ It would seem in such a case that the "but for" test would find jurisdiction: without those helicopters, there would be no helicopter crash. This jurisdictional basis moves up the stream of commerce, so to speak, froin the place of injury to the place of manufacture. It seems peculiar, however, to allow jurisdiction based upon these types of "upstream" contacts, when there is still a considerable anount of debate about whether jurisdiction should move downstream in products liability cases. ${ }^{216}$ Furthermore, as was pointed out in Helicopteros, United States exports could be adversely impacted if foreigu buyers became subject to Umited States law and United States courts for torts committed while using those goods. ${ }^{217}$

There are a couple of answers to this dilemma within the "but for" scheme. First, the historical/"but for" causation distinction could be invoked. Under this reasoning, even if the defendant had not purchased the helicopters in the forum, it would have been able to buy thein elsewhere. The analysis becoines inore difficult, however, if the instrumentality is of a unique nature which only one inanufacturer, located in the forum, is able to supply. Second, one could exclude purchases by proclaiming that they are not purposeful availment. In this case, the second part of the jurisdictional

210. Vermeulen I, 965 F.2d at 1016, 1026.

211. Id. at 1022-28.

212. 444 U.S. 286 (1980).

213. Id. at 288.

214. Id. at 297-98.

215. Helicopteros Nacionales de Colombia, S.A. v. Hall, 466 U.S. 408, 426 (1984) (Brennan, J., dissenting).

216. See supra note 79 and accompanying text (discussing the stream of commeree problem in products liability cases).

217. 466 U.S. at $425 \mathrm{n} .3$ (Brennan, J., dissenting) (according to respondents, the Solicitor General's amicus curiae brief made this point). 
test is not satisfied even if the contact is related. The problem with this solution is that if the purchases involved a visit to the forum, as was the case in Helicopteros, the solution conflicts with the widely-accepted rule that physical presence in the forum is a strong indicator of purposeful availment. $^{218}$

\section{Would Other Causation Tests Work Better?}

The "but for" test has significant advantages as well as disadvantages. Perhaps its greatest advantage is familiarity because the concept of "but for" causation is known to lawyers and judges. The "but for" test also comports roughly with the personal jurisdiction policies set out in Part II. It is a loose test which gives the plaintiff a broad choice of forum. Yet it maintaims rougli proportionality, when, for example, it refuses to let product liability cases be brought anywhere that the manufacturer sells the defective product. ${ }^{219}$ Might some other form of causation besides "but for" retain these advantages while avoiding the disadvantages of the "but for" test?

The notion of a causal relationship between the contacts and plaintiff's mjury is present in many judicial opinions, even if no specific type of causation is discussed. Many courts speak of injuries that "arise out of" the contacts, language that suggests causality to many people. ${ }^{220}$ However, to find a true definition of "related" using the concept of causation, one must specify the type of causation that is required. Types of causation which are narrower than "but for" exist in the law: "proximate cause" and "substantial factor" are two notable examples. As we shall see, however, neither of these types of causation appear promising as a definition of "related."

It is particularly difficult to regard proximate or "legal" causation as a true definition of relatedness because proximate causation usually refiects a policy-based legal filter on "but for" causation. As Dean Prosser wrote, "[t]he term 'proximate cause' is applied by the courts to those more or less undefined considerations which limit liability even where the fact of causation is clearly established."221 Thus, declaring that proximate cause is the relatedness standard represents only a small step towards defining relatedness. Case law must develop a definition of what is and is not proxiinate in this context.

The First Circuit is the circuit that has come closest to adopting a proximate cause test. In 1990, at about the same time as the decision in Shute, that circuit described as "noteworthy" the fact that the forum contacts

218. Regarding this rule, see supra note 75 and accompanying text.

219. See supra Section 1II.B.5.

220. The association of "arising out of" with causation is not, however, recognized by the Sixth Circuit. "The law of this circuit [is] that the 'arising from' requirement is satisfied if the cause of action is 'related to' or 'connected with' the defendant's forum contacts ...." Third Nat'l Bank v. WEDGE Group Inc., 882 F.2d 1087, 1091 n.2 (6th Cir. 1989), cert. denied, 493 U.S. 1058 (1990).

221. Prosser, supra note 176, at 244. 
(advertising) were not the proximate cause of the plaintiffs' injury. ${ }^{222}$ Two years later, in United Electrical Workers v. 163 Pleasant Street Corp., ${ }^{223}$ that same circuit spoke approvingly of "legal cause," coupled with cause in fact, as a relatedness test, adding that "[i]n this inquiry, foreseeability is critical."224 Unfortunately, the court did not explicitly adopt the proxinate cause test or apply it in any understandable fashion. ${ }^{225}$

The social causal chains that arise in personal jurisdiction analyses are unlike the physical chains that occur in tort or criminal law. ${ }^{226}$ Therefore, notions of proximate cause cannot be borrowed fruitfully from those areas. One might inagine that those concepts would at least be useful for determining relatedness in tort cases. Unfortunately, however, the precedents only deal with distinguishing which tortious acts are proximate causes, and not all contacts are tortious.

"Substantial factor" is, as discussed above, a useful standard in certain types of injuries, those which occur only when there is an accumulation of sinaller causative factors. However, attempting to apply such a test to relatedness outside of cumulative harm cases risks confusion. Consider, for example, whether a television advertisement for Carnival Cruise Lines in the plaintiffs' home town is a substantial factor in a slip and fall injury on one of the Carnival's ships and is therefore related for personal jurisdiction purposes. The words "substantial factor" do not bring us any closer to answering this question.

222. Pizarro v. Hoteles Concorde Int'1, C.A., 907 F.2d 1256, 1260 (1st Cir. 1990) (Re, C.J., sitting by designation).

223. 960 F.2d 1080 (1st Cir. 1992).

224. Id. at 1089 .

225. The plaintiffs had alleged that a subsidiary's foreign parent violated ERISA and other laws when the subsidiary cut off medical benefits to retirees. The court held that the parent corporation's capital contributions to the subsidiary were unrelated to that cause of action, but that participation in labor contract talks was related. Id. at 1084, 1089. It is difficult to view such participation as a "but for" cause, let alone a proximate cause, of the benefit cutoff. "But for" cause would require proof that the subsidiary would not have cut off medical benefits if the parent's managers had not been present at the contract talks. Perhaps the court discussed the talks because it really wanted to base its decision on the degree of control the parent exercised over the subsidiary, as courts typically do when deciding whether to attribute a subsidiary's contacts to the parent for personal jurisdiction purposes. See supra Section III.B.4 for a discussion of parent-subsidiary personal jurisdiction.

226. Dean Prosser gave the following list of causal chains from tort cases where the existence of proximate cause was disputed:

The defendant neghgently drives his car so that it leaves the roadway and collides with a power line pole; this shuts off power from a traffic control box, traffic signals cease to function, and two other cars collide at an intersection. A power line pole brcaks, falls upon a telephone wire and charges it; the plaintiff's power shovel, elevated above the ground, comes in contact with the wire. A negligently driven car collides with a taxicab, which is rammed against the stone stoop of a building, where it becomes wedged among stones knocked down. While a wrecking car is attempting to remove the taxicab, a stone which has becn dislodged is loosened, and falls upon a bystander.

Prosser, supra note 176, at 270 (footnotes omitted). 


\section{IV \\ Alternative Definttions of "Related"}

\section{A. Substantive Relevance}

In 1980, Professor Brilmayer proposed an appealing test of relatedness termed "substantive relevance." She suggested that a forum contact be considered related if the contact is a "geographical qualification of a fact relevant to the merits."227 In other words, a forum contact is a fact whose proof would help the plaintiff prevail in the suit substantively.

The substantive relevance test mcludes much, but not all, of the activity that courts traditionally regard as support for personal jurisdiction. Inforum contract formation, for example, becomes a related contact for suits on the contract because the existence and content of the contract are facts that a plaintiff must prove in order to recover. Similarly, telephoming a defannatory statement into the forum is a related contact. In general, any inforum injury suffered by the plaintiff becomes related, provided, of course, that the injury can be properly attributed to the defendant.

On the other hand, substantive relevance rejects the outcome of Shute. Under the substantive relevance test, the plaintiffs have no need to prove the effects of advertismg on them in order to prevail on the merits, since the advertising does not help the plaintiffs establish the negligence or defective construction that led to the slip and fall. ${ }^{228}$ Accordingly, in most cases, advertising in the forum would be unrelated to the injury.

A significant benefit of the substantive relevance standard is its ease of application, because substantive law generally sets forth the elements that need to be proved, and only acts tending to establish those elements would be related. ${ }^{229}$ Consequently, the field of possible related contacts is quickly and decisively narrowed. Even more, this narrowing borrows from existing law governing a particular field, and thus becomes tailored to the policies of

227. Brilmayer, supra note 70 , at 82 .

228. However, ingenious lawyers faced with a substantive relevance test could reformulate the theory of the case. One idea is that plaintiffs could transform the suit into a "failure to warn" claim by asserting that the defendant's advertising failed to warn them that slipping and falling on the cruise ship was a possibility. This kind of transformation is a general device for stretching jurisdiction as well as for adding defendants, but courts may not take kindly to it. See, e.g., Saudi Arabia v. Nelson, $113 \mathrm{~S}$. Ct. 1471,1480 (1993) (" $[\mathrm{A}]$ plaintiff could recast virtually any claim of intentional tort . . . as a claim of failure to warn, simply by charging the defendant with an obligation to announce its own tortious propensity before indulging it.").

229. If these elements are unclear because there is dispute as to which state's law will apply, Professor Brilmayer suggests that jurisdiction be determined by whether a contact is related "under a law that arguably will govern the issue." Brilmayer, supra note 70, at $83 \mathrm{n} .39$. This standard is analogous to the widely accepted rule that plaintiffs need only make out a prima facie case for the facts underlying personal jurisdiction. See, e.g., Cronin v. Washington Nat'l Ins. Co., 980 F.2d 663, 670 (1 lth Cir. 1993) (basing personal jurisdiction on an alleged contract which was ultimately found not to exist); see also Boit v. Gar-Tec Prods., 967 F.2d 671, $674-78$ (1st Cir. 1992) (discussing standards of proof for jurisdictional facts). 
that field, even if no court has previously considered personal jurisdiction in that area.

No circuit has adopted the substantive relevance standard unequivocally. However, the First Circuit recently expressed some approval of the test in dictum, writing that "the defendant's in-state conduct must form an 'important, or [at least] material, element of proof' in the plaintiff's case." ${ }^{\text {230 }}$ The results reached by the inore anti-jurisdiction circuits-the First and Eighth - can be explained to a certain degree by substantive relevance. However, there are cases in both the First and Eighth Circuits which fail to find jurisdiction where substantive relevance would secm to find it.

In Crocker v. Hilton International Barbados, Ltd., ${ }^{231}$ the First Circuit found the act of making a prepaid hotel reservation froin the forum unrelated to an alleged breach of the resulting implied covenant of habitability. ${ }^{232}$ The court held that "the implied covenant ... arises when the guest checks $\dot{m}$, is assigned some specific space, and receives a key or other means of access to that space., ${ }^{.233}$ These acts had, of course, taken place outside of the forum. Perhaps the rule resulting from Crocker is that a forum contact is not related to a suit on a legal obligation if the contact took place before the obligation arose-for example, if it occurred before all conditions precedent were met. ${ }^{234}$ By contrast, the substantive relevance test would consider the formation of a contract related to all causes of action claiming a breach of that contract.

Similarly, in Morris v. Barkbuster, Inc., ${ }^{235}$ the Eighth Circuit found no personal jurisdiction in Minnesota over the Arizona designers of an allegedly defective log-splitter which caused the plaintiff to lose both arms. ${ }^{236} \mathrm{~A}$ Minnesota company had purchased the design from the designers and had manufactured the particular log-splitter which injured the plaimtiff. The Eiglith Circuit found the sale of the dcsign unrelated to the cause of action, ${ }^{237}$ but under a substantive relevance test, the sale would have been a related contact because the sale inust be proved to show that the allegedly

230. United Elec. Workers v. 163 Pleasant St. Corp., 960 F.2d 1080, 1089 (1st Cir. 1992) (quoting Marino v. Hyatt Corp., 793 F.2d 427, 430 (1st Cir. 1986)) (bracketed material added by court).

231. 976 F.2d 797 (1st Cir. 1992). This case applied the Massachusetts long-arm statute. However, the First Circuit previously had held that "arising from" in that statute "mirrors" the constitutional relatedness requircment. United Elec. Workers, 960 F.2d at 1087.

232. $976 \mathrm{~F} .2 \mathrm{~d}$ at 801 .

233. Id. at 801 . The court cited no authority for this rule. Nor did it discuss whether this is a rule of forum law or of the law of Barbados, where the hotcl was located.

234. Compare Crocker with Hahn v. Vermont Law School, 698 F.2d 48 (1st Cir. 1983). The law school had mailed the plaintiff's letter of acceptance into the forum. Id. at 49 . That contact was held related to the law school's hreach of the resulting contract by giving the plaintiff an F in a course. Id. at 50. Could it not just as well have heen said in Hahn that the legal obligation to grade fairly arose only when the plaintiff chose to enroll in that particular course?

235. 923 F.2d 1277 (8th Cir. 1991).

236. Id. at 1279,1283 .

237. Id. at 1281. "[A]ny relation . . . is, at best, highly attenuated, and insufficient to support Minnesota's exercise of jurisdiction ...." Id. at 1283 . 
defective log-splitter was actually built to the Arizonans' design specifications.

In summary, substantive relevance is an easily applied, narrow test that captures many situations where courts generally would find contacts to be related. In some cases, like those noted above, the test would likely result in jurisdiction when it would not otherwise have been found. On the other hand, the test generally denies jurisdiction in certain more difficult situations, where courts often find that jurisdiction should exist, as in Shute. As such, the test, in spite of its appeal, is unsuitable for general use because it can contradict courts' intuitions regarding just outcomes.

\section{B. "Could Have Been" Causation}

In contrast to the narrow substantive relevance test, the "could have been" causation test stretches to the outer limits of relatedness. Under that test, forum contacts are related if they increase the ex ante probability that the events giving rise to the lawsuit would occur. To put it another way, contacts are related if the forum contacts "could have been" the cause of those events.

For a simple example of how the "could have been" test works, consider a small variant on the fact pattern in Shute. Suppose that Carnival Cruise Lines' lawyers were able to establish that the Shutes never saw the company's advertisements, but rather went on the cruise based upon a word-of-mouth recommendation from a friend living in another state. In such case, even if the advertisements were unequivocally slown not to be a "but for" cause of the cruise, there is nonetheless jurisdiction over Carnival Cruise Lines under a "could have been" test because the advertising could have influenced, and was in fact intended to influence, the Shutes' decision to take the cruise.

The justification for imposing jurisdiction on the basis of "could have been" causation is that the defendant was deliberately increasing the risk of a lawsuit through the contacts in question. Stated differently, from the defendant's point of view, it should be considered an immaterial randoin happening that the events giving rise to the lawsuit occurred without involving the forum contacts directly in the causal chain.

The "could have been" test can be seen as a jurisdictional analog of the much-debated proposal to define causation for substantive tort purposes as an increased probability of harm. ${ }^{238}$ Under this definition, a plaintiff's cancer would be caused by any act which makes that type of cancer more

238. See, e.g., Richard W. Wright, Causation, Responsibility, Risk, Probability, Naked Statistics, and Proof: Pruning the Bramble Bush by Clarifying the Concepts, 73 IowA L. REv. 1001, 1042-43 (1988) ("According to the proponents of 'probabilistic causation,' a condition was a cause of some result if it increased the probability-risk-that the result would occur.'); see also Jean M. Eggen, Toxic Reproductive and Genetic Hazards in the Workplace: Challenging the Myths of the Tort and Workers Compensation Systems, 60 Fordham L. Rev. 843, 888-93 (1992) (describing the cautious judicial acceptance of liability based on the creation of risk in particular situations). 
probable, such as a toxic spill, the manufacture of chlorofluorocarbons which deplete the earth's ozone layer, or smoking in a public place. However, in the tort examples above, the harshness of the rule can be mitigated by letting the plaintiff recover only the portion of his injury corresponding to the likelihood that the defendant's act caused the harm. ${ }^{239}$ It is difficult to design a jurisdictional analog to this mitigating rule.

The courts have never explicitly applied a "could have been" jurisdictional rule, but there are occasional cases that appear to invoke similar reasoning. Perhaps the clearest example is Cubbage v. Merchent, ${ }^{240}$ decided by the Ninth Circuit in 1984. The plamtiff brought suit in California against a hospital and two doctors who treated him in an Arizona town just across the border from California. The defendants lad obtained a Medi-Cal reimbursement number and advertised in a telephone directory distributed in both states. ${ }^{241}$ The court found these acts to be related contacts, ${ }^{242}$ even though there was no indication that the ad in the teleplione directory had induced the plaimtiff to contact the hospital or that the plaintiff was a MediCal patient. In this sense, the ad was a "could have been" cause of the injury, given some nonnegligible chance that the plaintiff might have looked for a doctor by consulting that directory. The Medi-Cal number is more difficult to construe even as a "could have been" cause, since therc was no imdication that plaintiff was a Medi-Cal patient. Nevertheless, the case may be viewed as a Ninth Circuit endorsement of "could have been."

The Fourth Circuit products liability case, Lee v. Walworth Valve Co. ${ }^{243}$ is another example of "could have been" reasoning. The plaintiff's husband had been killed by an allegedly defective valve nianufactured by the defendant. Altlough the particular valve that caused the injury had not bcen purchased in the forum, the defendant manufacturer sold the saine product there. ${ }^{244}$ The court relied on this contact to find jurisdiction. ${ }^{245}$

239. See Eggen, supra note 238 , at 893 . Under current substantive "toxic tort" law, in contrast, a plaintiff must establish a greater than $50 \%$ chance that the cancer resulted from the defendant's act. See Steve Gold, Note, Causation in Toxic Torts: Burdens of Proof, Standards of Persuasion, and Statistical Evidence, 96 YALE L.J. 376, 384-86 (1986). When this threshold is passed, however, the plaintiff gets $100 \%$ recovery.

240. 744 F.2d 665 (9th Cir. 1984), cert. denied, 470 U.S. 1005 (1985).

241. Id. at 666-67. Medi-Cal is California's state medical insurance program for low-income patients.

242. Id. at 670 .

243. 482 F.2d 297 (4th Cir. 1973); see discussion supra notes 205-07 and accompanying text.

244. Lee, 482 F.2d at 298-99.

245. Id. at 300-01. Cases like Lee are generally explained in terms of the defendant's in-forum acts being "similar" to the out-of-forum acts giving rise to the litigation. For example, in Lee, the outof-forum sale of the defective product is similar to in-forum sales of the product. See Twitchell, supra note 36, at 660-62 (arguing for jurisdiction based on similar acts).

Another court of appeals case arguably invoking "could have been" is Southwire Co. v. TransWorld Metals \& Co., 735 F.2d 440 (11th Cir. 1984). In discussing the relatedness of in-forum solicitation to a breaeh of contract claim, it reasoned that even if the salcs representative had entered the forum to sell one kind of product and a "somewhat different type" of order eventually resulted, the salcs visit was close enough to count. Id. at 445 . The court's decision is somewhat suspect, however, 
The Supreme Court may have also considered a "could have been" analysis when it discussed relatedness for choice of law purposes in Allstate Insurance Co. v. Hague. ${ }^{246}$ The plaintiff's husband had a fatal traffic accident in Wisconsin, where he lived. In a subsequent lawsuit brought in a Minnesota court, the laws of Minnesota were applied and the plaintiff was awarded an insurance payout greater than what she would have received under Wisconsin law. ${ }^{247}$ The Supreine Court found the choice of law constitutional because the cause of action was related to Minnesota. ${ }^{248}$ The Court noted that the husband commuted daily into Minnesota and that the insurance policy covered hin there. From this, the Court concluded that the insurance company should have expected that an accident could have occurred in Minnesota. ${ }^{249}$ The fact that the insurance policy in Hague covered risks in Minnesota is certainly a "could have been" cause of the payout, because the husband's traffic risk in Minnesota increased the likelihood that the insurer would have to pay out, as coinpared with insuring only risks in Wisconsin.

One difficulty with the "could have been" test is deciding how small an increase in probability will suffice for jurisdiction. Suppose, for example, that I advertised a product in the Los Angeles Times, and a Californian who responded to the ad atteinpts to sue ine in New York on a cause of action relating to the product. After all, the Californian argues, there are a few homesick Angelenos in the Big Apple who subscribe to the Los Angeles Times, and my advertisement increased the probability that someone in New York would buy my product, even if ever so shightly. Is that small increase in probability enough to meet the "could have been" test?

A further difficulty with "could have been" causation can be seen by considering its application in auto accident cases. Suppose a Boston resident gets into an accident in Boston with a driver from New Hampshire. Suppose further that the New Hampshire driver wants to sue the Bostonian in New Hampshire. Would jurisdiction be available if the Bostoman makes frequent trips to New Hainpshire to ski, and those trips "could have been" (even though they actually were not) the cause of the accident?

To summarize, the "could have been" causation test lies at the outer limits of relatedness. It accords with prevalent notions of enterprise liability and liability for risk creation. However, this test also opens a Pandora's box, which is probably wlyy courts have not adopted it. "Could have been" causation is, thus, an exainple of a widely-held policy intuition that cannot be transformed into a legal rule.

because it followed state court precedent purporting to interpret the state long-arm statute and did not make an independent federal constitutional analysis. Id. at 442 .

246. 449 U.S. 302, 313-20 (1981) (plurality opinion).

247. Id. at $305-06$.

248. Id. at 320 .

249. Id. at 314,318 n.24; id. at $329 \&$ n.22 (Stevens, J., concurring). 


\section{Sliding Scales}

Professor Richman has suggested a sliding scale of relatedness. "As the quantity and quality of the defendant's forum contacts increase, a weaker connection between the plaintiff's claim and those contacts is permissible; as the quantity and quality of the defendant's forum contacts decrease, a stronger connection between the plaintiff's clain and those contacts is required."250

The Sixth Circuit lias endorsed this kind of test in dictum. ${ }^{251}$ Shute also suggested that "where a defendant has only one contact with the forum state, a close nexus between its forum-related activities and the cause of the plaintiffs' harm may be required."252 However, there do not seein to be any cases actually applying a sliding scale of this type. ${ }^{253}$ The reason for this is probably that in practice, a sliding scale test would be so coinplex as to be ineaningless. Eacli case would turn on its own particular facts and thus predictability, one of the inajor policy goals applicable to personal jurisdiction, would disappear. The Supreme Court in Helicopteros could have adopted a test which balanced relatedness against the ainonnt of forum involveinent, but it did not. ${ }^{254}$ Justice Blackinun, the author of the Helicopteros majority opimion, was certainly aware of the possibility of sucli balancing, since lie devised the Eighth Circuit's five-factor balancing test when he sat on that court. ${ }^{255}$

\section{Applying the Different Tests: Burnhain v. Superior Court}

To recapitulate the relatedness tests, consider wliether jurisdiction should have been found in Burnham v. Superior Court under a ininimuin contacts theory. ${ }^{256}$ The plaintiff was the defendant's estranged wife and

250. William M. Richman, A Sliding Scale to Supplement the Distinction Between General and Specific Jurisdiction, 72 CALIF. L. REv. 1328, 1336, 1345 (1984) (review essay).

251.

If the contract had borne a more substantial relationship to Michigan, it would not have becn necessary for the representations it embodied actually to have been made to the plaintiff in Michigan. Where the defendant's contacts with the forum state are as attenuated as they are here, however, we think it is incumbent on the plaintiff to show affirmatively that the fraudulent misrepresentations were actually made in the forum state.

LAK, Inc. v. Deer Creek Enters., 885 F.2d 1293, 1303 (6th Cir. 1989) (citations omitted), cert. denied, 494 U.S. 1056 (1990).

252. Shute v. Carnival Cruise Lines, 897 F.2d 377, 385 n.7 (9th Cir. 1990), rev'd on other grounds, 499 U.S. 585 (1991).

253. However, in Holt Oil \& Gas Corp. v. Harvey, 801 F.2d 773, 779 (5th Cir. 1986), cert. dented, 481 U.S. 1015 (1987), the court may have lowered the general jurisdiction threshold because there were some related contacts which were insufficient in themselves to justify specific jurisdiction. See Bearry v. Beeeh Aircraft Corp., 818 F.2d 370, 376-77 (5th Cir. 1987) (cxplaining the court's reasoning in Holl).

254. Helicopteros Nacionales de Colombia, S.A. v. Hall, 466 U.S. 408, 413-14 (1984).

255. See Aftanase v. Economy Baler Co., 343 F.2d 187, 197 (8th Cir. 1965).

256. 495 U.S. 604 (1990). In this complex case, four Justices said it was enough that there was instate service of process, and no minimum contacts analysis was necessary. See id. at 616-19 (Scalia, J.) (joined by Rehnquist, C.J., Kennedy \& White, JJ.). Four other Justices, however, purported to find that in-state service of process always satisfies the minimum contacts test, at least in a policy sense. See id. 
was suing him for divorce. The couple had previously lived on the East Coast, but after the marriage ran into difficulties, the wife and children moved to California. ${ }^{257}$ The husband was served while he was visiting his ex-wife and children during a short busmess trip to California. ${ }^{258}$

Under the substantive relevance test, a court would likely decline jurisdiction because the wife did not need to prove that her husband visited lier in order to prevail on her property distribution or child support claims. Accordingly, the visit would not be related to the cause of action.

Similarly, the visit would not be related under the "but for" causation test. The plaimtiff had made up her mind to get a divorce before the visit; in fact, she had made an agreement with her liusband that she would file for it. ${ }^{259}$ As such, the visit was clearly not a "but for" cause of the divorce.

It is likely that a court would also deny jurisdiction under a "could have been" causation test. Because the couple had already agreed upon the divorce, the husband's visit did not increase the probability of the divorce's occurrence and is therefore not related.

One can only conclude that in Burnham, the defendant's visit lay at or beyond the outer boundaries of relatedness. To find minimum contacts in Burnham based on the visit, one must turn to the test of last resort, devised by Professor Brilmayer. This test, known as "relatedness in ternis of storytelling," 260 proclaims that a contact is related if mentioning the contact would not seein too great a digression when narrating the facts of the case.

$\mathrm{V}$

\section{A Solution: A Baseline Test with SubJect-Area EXCEPTIONS}

\section{A. The Need for Some Sort of Rule}

After looking at various relatedness tests and finding none entirely satisfactory, it is teinpting to take a step back. Where rules become difficult to

at 630 (Brennan, J.) (joined by Blackmun, Marshall \& O'Connor, JJ.) (reaffirming the need to test all assertions of jurisdiction against "contemporary notions of due process" and expressing continuing belief in minimum contacts analysis); $i d$. at 639 (concluding that in-state service of process is always sufficient to establish personal jurisdiction). The following analysis in the text is relevant only to the latter Justices' views.

257. Id. at 607 .

258. Id. at 608 .

259. Id. at 607 .

260. Lea Brilmayer, Related Contacts and Personal Jurisdiction, 101 HARv. L. Rev. 1444, 145255 (1988). The analysis might turn out differently, however, if contacts other than the defendant's visit to the forum are considered. For example, the Court might have considered the presence of the defendant's wife and children in the forum, though that should probably not count as a contact, because it was not an intended act of the defendant or the foresecable consequence of an intended act. $C f$. Kulko v. Superior Court, 436 U.S. 84, 94 (1978) (holding that defendant's conscnt to his daughter's moving into the forum is not purposeful availment). The Court might also have considered the fact that the separation agreement explicitly contemplated the wife's move to California as a related contact for the husband. Kulko again suggests that this was not purposeful availment, id. at 87 , but there is more room for dispute here. 
apply or reach counterintuitive results, perhaps the best approach is to avoid rules altogether and rely on more flexible standards. The desirability of having a suit heard in one state versus another is undoubtedly the result of many factors. Balancing tests are commonplace in American law; in a sense, balancing is the default way to formulate a legal test. Perhaps, then, personal jurisdiction should be decided by a balancing test as well. The most relevant factors could be set forth and the courts could weigh the factors on a case by case basis to reach a fair decision. ${ }^{261}$

Balancing tests, flexible standards, and discretion are indeed the correct answer in many legal contexts. However, they are not the proper approach to personal jurisdiction because the value of certainty and predictability outweighs the advantage of getting the "right" answer in individual cases.

\section{Why Certainty and Predictability?}

Certamty and predictability are iınportant in determining personal jurisdiction for two reasons. First, they are central to achieving the policy goal of nonaffiliation. For nonaffiliation to work, legal outcomes nust be predictable enough to allow lawyers the opportunity to design a safe course of conduct which will allow an economic actor to avoid being subject to the laws of a certain state. Second, certainty and predictability make the judicial system more efficient because they avoid costly disputes. Personal jurisdiction claims arise constantly and consume a nonnegligible fraction of our total judicial resources, ${ }^{262}$ suggesting that the present system is not working.

The Supreme Court has often said that predictability of jurisdictional outcomes is desirable. Justice Stevens expressed this inost clearly when he wrote that defendants should have

fair warning that a particular activity inay subject a person to the jurisdiction of a foreign sovereign. If I visit another State, or acquire real estate or open a bank account im it, I knowingly assume

261. The Eighth Circuit still purports to use a balancing tcst to decide personal jurisdiction cascs. See supra note 94 and accompanying text. The prevailing test for personal jurisdiction contains a balancing test in the reasonableness fork. See supra note 84 and accompanying text. Some commentators view balancing tests as the best way to reconcile all of the personal jurisdiction decisions. See, e.g., Eugene F. Scoles \& Peter Hay, Conflict of Laws 307 (1982) ("[P]roblems . . . may preclude the formulation of a simple yet all encompassing test. . . There probably is a sliding scalc of the scope of jurisdiction . . . ."); Richard K. Greenstein, The Nature of Legal Argument: The Personal Jurisdiction Paradigm, 38 Hastings L.J. 855, 856-57 (1987) ("[T]he constitutional dimensions of jurisdiction over persons [are defined] as comprising a group of specific, intertwined, but irreconcilable themes .... [W] [hat appears in the conventional view of jurisdiction to be abrupt shifts in doctrine or inconsistent decisions, simply reflects the ever shifting relationship among the themes."). Another commentator scorns this as a "laandry list approach." Maltz, supra note 61, at 1055.

262. See Robert C. Casad, Personal Jurisdiction in Federal Question Cases, 70 TEx. L. Rev. 1589, 1590 (1992) (noting that personal jurisdiction cases represent "a large share of reported state and fcderal decisions"). 
some risk that the State will exercise its power over my property or my person while there. My contact with the State, though minimal, gives rise to predictable risks. ${ }^{263}$

Predictability was also emphasized in World-Wide Volkswagen Corp. $v$. Woodson, ${ }^{264}$ whicli described the question whether "the defendant's conduct and connection with the forum State are sucli that lie should reasonably anticipate being lialed into court there" as "critical to due process analysis."265 Likewise, in Burnham v. Superior Court, ${ }^{266}$ Justice Scalia described "uncertainty and litigation over the preliminary issue of the forum's competence" as "evils."267

Of course, predictability as a policy objective by itself fails to lead to specific rules. Suppose, for example, that personal jurisdiction rules were abolished; state courts could then indiscriminately hear suits against any non-forum defendant. Anyone could be sued anywliere as a consequence of any activity. Being subject to suit in all those places might be unpleasant, but it would be perfectly predictable and foreseeable, at least to anyone with proper legal advice. ${ }^{268}$

Nonetheless, predictability suggests that, all else being equal, preference sliould be given to rules that are clear and simple. The terms used in rules should be words whose referents are as easy to determine as possible. Categorical rules are also preferable to balancing tests, because tlere are at least some cases where the categorical tests are undeniably satisfied. All of this, of course, is subject to the condition that whatever rules one designs, the rules inust be consistent with social and judicial intuitions about fairness.

\section{The Limited Value of Getting the "Right" Answer}

In many legal contexts, clarity and certainty are valuable, but are nonetheless sacrificed for the "right" answer. In divorce, for example, litigation costs often serve to furtlier impoverish parties whose standard of living has

263. Shaffer v. Heitner, 433 U.S. 186, 218 (1977) (Stevens, J., concurring).

264. 444 U.S. 286 (1980).

265. Id. at 297.

266. 495 U.S. 604 (1990).

267. Id. at 626 (Scalia, J.); see also Coté v. Wadel, 796 F.2d 981, 983 (7th Cir. 1986) (Posner, J.) ("Jurisdictional rules should be as simple as possible, so that the time of litigants and judges is not wasted deciding where a case should be brought and so that fully litigated cases are not set at naught... because a subtle jurisdictional bar was overlooked until the appeal.").

268. Perhaps, bowever, what the Supreme Court meant by "reasonably anticipate being haled into court there" was not the kind of prediction a lawyer would make, but the kind of intuition an untutored lay individual would have as to where jurisdiction would lie. When educated people feel weighed down by their own knowledge and sophistication, they sometimes imagine that a decision would be easier if knowledge and sophistication could be stripped away. Cf. Duck Sour (Paramount Pictures, Inc. 1933) (Minister of Finance: "Your Excellency, here is the Treasury Department's report. I hope you'll find it clear." Rufus T. Firefly, played by Groucho Marx: "Clear! Huh? Why, a four-year-old child could understand this report. Run out and find me a four-year-old child.") (screenplay reconstructed in THE Four Marx Brothers in Monkey Business and Duck Sour 94, 120 (1972)). 
already declined because of the marital breakup and its consequences. ${ }^{269}$ Nonetheless, states often leave property division in divorce cases to broad principles of "equitable" division because it is imperative that judges have freedom to find the right answer. ${ }^{270}$

The value of getting the correct answer im personal jurisdiction cases is often negligible, however. There are two reasons for this, one practical and the other theoretical. First, the difference im the cost of fighting a lawsuit in one place or another is imsignificant when compared to the lawyers' fees. ${ }^{271}$ This is particularly true if one looks at the increase im total cost rather than the cost shift between the parties, smce one party's loss is often the other's gaim.

Second, even if the personal jurisdiction decision would provoke a large cost increase in a given case, the policies behind personal jurisdiction, as discussed im Part II, do not push courts very strongly and decisively in one direction. In a sense, that is because the most powerful policies are systemic ones like nonaffiliation and proportionality, and are served by any kind of standard, even a rather arbitrary one.

\section{B. Splitting the Test}

No smgle relatedness rule fits all situations where personal jurisdiction is at issue, as illustrated im Parts III and IV. But, as the preceding section argued, having no rules and employing a vague standard is also unacceptable. A possible answer lies in splitting the relatedness test into two or more distinct rules. The split should leave a baselme rule applicable to most cases and could be complemented by exceptions that would apply to certain types of cases.

This method is not an uncommon way of organizing legal rules. For exanuple, the time for filing a lawsuit is generally governed by a bright-lime baseline rule, the statute of limitations. Sometimes, however, when the statute of limitations would lead to unjust results, the statute is tolled in order to protect the potential plaintiff. ${ }^{272}$

The discussion im Part IV suggests that the baseline rule for relatedness should be substantive relevance. That rule is the inost consistent with the

269. See, e.g., Mark A. Sessums, What Are Wives' Contributions Worth Upon Divorce?: Toward Fully Incorporating Partnership Into Equitable Distribution, 41 FLA. L. REv. 987, 1026 (1989).

270. See LaWrence J. Golden, Equttable Distribution of Property $\$ 2.06$ (1984).

271. Indeed, law firms may often have a conflict of interest with their clients in raising objections to personal jurisdiction. Consider the decision to object to jurisdiction from the point of view of the defendant's regular law firm. If that firm has no branch office in the distant forum and the suit takes place there, it will have to hire local counsel and share the business. The client might even give the entire lawsuit to the local counsel, in which case the firm loses all of the business. On the other hand, if the firm objects to jurisdietion, it gets to charge the chent the cost of making that motion, gets a delay of some montha while the motion is deeided, and has at least a fighting chance of keeping the business all to itself.

272. See, e.g., Diaz v. Shallbetter, 984 F.2d 850, 853-54 (7th Cir. 1993) (creatively employing a state tolling rule to get around a federal rule). 
case law and has the great merit of clarity. Moreover, the test extends naturally to even obscure legal subject areas and peculiar causes of action because its content is derived from the substantive law.

The strictness of the substantive relevance test is another advantage because deviation from the baseline rule will normally occur in only one direction, that of considering a contact related where the baseline rule does not. This deviation accords with the fact that only denials of jurisdiction are immediately appealable in the federal system. ${ }^{273}$ If district courts apply the basehne rule strictly, they will deny jurisdiction in cases not falling within a recognized exception. Appeals of these decisions will quickly reach the circuit courts and those courts can weigh the factors that favor recognizing a further exception.

\section{Subject-Area Rules}

Some exceptions to the baseline rule are necessary so that personal jurisdiction doctrine better approximates society's visions of fairness. This Section suggests that the exceptional rules should apply im specific legal subject areas. The courts' experience with relatedness over the past decades suggests that only a few exceptions will be needed.

\section{Two Proposed Exceptions}

The two exceptions most clearly suggested by the caselaw are these:

1) Forum contacts by a party to a contract, which would be related to a suit for breach of that contract, are also related to a suit against that party for a tort committed in the course of performing the contract.

2) The sale of a product in the forum is related to a clain that an identical product caused harm to a forum resident because of a defect.

The first exception is inspired by the facts of Shute, while the second derives from the product liability problems discussed in Section III.B.5.

The first subject-area rule is justified because torts committed in the course of performing a contract are unique. In such cases, the tortious act is usually the misperformance of a contractual obligation. ${ }^{274}$ Plaintiffs in such cases sue for tort rather than breach of contract primarily because a broader range of damages is available in tort. Plaintiffs suing im contract would be

273. See 15A Charles A. Wright et al., Federal Practice and Procedure § 3914.6, at 52631 (2d ed. 1992).

274. Our legal system classifies such an act as a tort rather than a breach of contract for a variety of historical and practical reasons. See ProssER, supra note 176, at 613-22 (discussing the relationship between torts and contracts). 
limited by the rule against einotional distress damages and the rule of Hadley v. Baxendale, ${ }^{275}$ neither of which apply in tort. ${ }^{276}$

As our legal systein developed, the line between tort and contract inoved. Sometimes inedical inalpractice tort liability coexists with contract liability. ${ }^{277}$ Defective products liability was long conceptualized as mainly contractual. Even today, implied warranties subsist alongside tort liability for defective products, even though the two causes of action are virtually identical. ${ }^{278}$ A landlord's inplied warranty of habitability can often cover the same territory as his or her neghigence liability. ${ }^{279}$ All this suggests that in the special case of torts committed while performing a contract, the tortcontract distinction is not substantively ineaningful, and thus, should not be used as the basis for determining whether personal jurisdiction exists.

The second subject-area exception could be justified on the ground that products liability is a substantively unusual area of law. Enormous liability is miposed without fault and the basic law was created entirely by judges in response to a specific social need and in spite of almost total legislative inaction. ${ }^{280}$ In addition, a special "enterprise liability" theory is used which brings tort closer to social insurance. These facts suggest that policy is especially favorable towards plaintiffs in this area. In keeping with this policy, an injured plaintiff should not be penalized for having purchased the defective product away froin home. ${ }^{281}$ Furthernore, the second exception is tightly focused on the products liability area and on solving a specific practical difficulty. As such, the exception would not produce the broad implications that adoption of the "could have been" test would have.

275. 156 Eng. Rep. 145 (Ex. Ch. 1854).

276. See 3 E. Allan Farnsworth, Contracts $\$ \S 12.14,12.17$ (2d ed. 1990) (discussing Hadley v. Baxendale and emotional distress damages in contract).

277. The classic example of this is Hawkins v. McGee, 146 A. 641 (N.H. 1929), where the doctor was foolish enough to promise a specific medical outcome and was held liable for the plaintiff's resulting expectation damages.

278. James J. White \& Robert S. SUMmers, Uniform Commerctal Code 387-88 \& n.3 (3d ed. 1988) (noting that in a defective product case, "the buyer's attomey often will be able to plead at least four causes of action: breach of an express warranty, breach of the implied warranty of merchantability, strict tort liability, and negligence in the manufacturing of the defective product") (citations omitted).

279. See 2 Restatement (SECOND) OF Property reporter's note to introductory note to ch. 17, at 158 (1977) ("[t]he duty which is imposed as a necessary part of the lcase arrangement and the duty which forms the basis for tort liability" can only be kept separate by "rigid intellectual compartmentalization and definitional formalism").

The plaintiffs in Crocker v. Hilton Int'1 Barbados, Ltd., 976 F.2d 797 (1st Cir. 1992), discussed supra notes 231-34 and accompanying text, invoked an implied warranty of habitability in their attempt to exercise jurisdiction over the hotel where they were injured. The court declined jurisdiction on relatedness grounds.

280. See Prosser, supra note $176, \S 98$.

281. The rule as suggested will not find specific jurisdiction where the manufacturer has refused to sell the product in the forum. For example, no specific jurisdiction would exist for a products liability claim on a "gray market" Porsche 956, or on a drug whose foreign manufacturer feels American sales would be too low to justify the cost of obtaining FDA approval. 


\section{The Advantages of Subject-Area Rules}

Subject-area rules for personal jurisdiction are desirable for three reasons. First, judges' substantive intuitions regarding fairness and the balancing of interests are clearer when confined to a specific subject area. As discussed in Part II.A, although the allocation of costs between plaintiffs and defendants is a central question in determining personal jurisdiction, it is difficult to have any clear notions about where to draw the line when one is making rules that have to apply to all plaintiffs, all defendants, and all causes of action.

Consider a judge who is faced with a specific case, perhaps a slip and fall case like Shute. Suppose that the judge wishes to find jurisdiction by adopting a general relatedness test like "but for" causation. Such a judge inust consider an assortment of other cases in order to determine if applying the "but for" test is desirable. For instance, the judge might consider possibilities like the Harvard Law School graduate who practices in California but is sued for malpractice in Massachusetts, discussed in Section III.B. Conversely, if a rule is limited by subject area, the potential implications that a judge must consider are much easier to grasp because the fact patterns will likely be similar. In fact, many of the implications will be evident from the dispute that gave rise to the rule.

Second, the procedural interests across subject areas may be different. For example, different kinds of hitigation present different incentives for picking forums because in some cases, inconvenient forums may have a greater impact on a particular kind of defendant or plaintiff. One particular kind of plaintifff that would be greatly affected by the choice of forum is a consumer. It is one thing for a inail-order company in Maine to sue a Californian in Maine on a billing dispute, and quite another thing for the Californian to sue the Maine company in Cahformia on a products liabihity claim. Allowing the suit in the billing dispute could lead to an unjust default judgment, 282 whereas the incremental cost of being forced to pursue the products liability claim in Maine miglit inean, in a inarginal case with modest injury, that the plaimtiff could not find a law firm willing to take the case on a contingency-fee basis.

Third, simce rules limited by subject area can be fornulated in terms of concepts specific to that area of law, the rules can be more specific and thus more predictable in their application. To judge by the difficulties courts encounter when applying general concepts like "but for" causation, such specificity seems highly desirable.

Commentators liave occasionally argued for different jurisdictional rules in different substantive areas. For example, Professors Carrington and

282. See Purcell, supra note 98 , at $453-54$ (discussing how merchants and finance companies use inconvenicnt venues within the state of New York to obtain default judgments). 
Martin argued for this idea in $1967,{ }^{283}$ although Carrington has since changed his position. ${ }^{284}$ Recently, Professor Borchers has argued that the United States should nodel its jurisdictional rules after the European jurisdiction-regulating treaty, the Brussels Convention. ${ }^{285}$ Indeed, that treaty has the considerable nerit of having been negotiated by truly sovereign states, each taking into account its individual interests. It thus reflects the kind of state sovereignty interests that are often said to underlie American doctrines of personal jurisdiction. The actual European jurisdictional rules are unfortunately far too pro-defendant for the United States to consider adopting. ${ }^{286}$ However, the treaty's idea of having separate rules for distinct subject areas ${ }^{287}$ is worth imitating.

Courts have some subject-area jurisdictional rules now, but not niany. Shaffer v. Heitner ${ }^{288}$ reaffirmed the existence of special jurisdictional rules for divorce and child custody. ${ }^{289}$ Judge Weinstein recently devised and applied a special theory of personal jurisdiction for mass DES torts. ${ }^{290}$ Occasionally there have been other hints at subject-area specialization, such as the Tenth Circuit's view that "[i]n the context of doctor-patient litigation, special rules have evolved."291

283. Paul D. Carrington \& James A. Martin, Substantive Interests and the Jurisdiction of State Courts, 66 Mich. L. Rev. 227, 230 (1967).

284. See Paul D. Carrington, Making Rules to Dispose of Manifestly Unfounded Assertions: An Exorcism of the Bogy of Non-Trans-Substantive Rules of Civil Procedure, 137 U. PA. L. Rzv. 2067, 2068 (1989) ("[J]udicially-made rules directing courts to proceed differently according to the substantive nature of the rights enforced is an idea that ... must be rejected for the present and for the future.').

285. Patrick J. Borchers, Comparing Personal Jurisdiction in the United States and the European Community: Lessons for American Reform, 40 AM. J. Comp. L. 121, 121-23 (1992).

286. For example, when a company does business in a European Community country, it is amenable to suit on "related" disputes only when it has an office or similar place of business in the country. Brussels Convention on Jurisdiction and Enforcement of Judgments in Civil and Commercial Matters, done on Sept. 27, 1968, art. 5, 1990 O.J. (C 189) 1, 4 (unofficial amended tcxt). In other words, it is only amenable to suit in places where, under American rules, it would probably be subject to general jurisdiction.

Although pro-defendant in general, the European Community rules are favorable to consumer plaintiffs. Id. arts. 13-14, 1990 O.J. (C 189) at 6-7 (stating that a consumer may sue at home, and can be sued only at home, on most consumer contracts).

287. See id. arts. 5-18, 1990 O.J. (C 189) at 4-8. National venue rules are often also split by

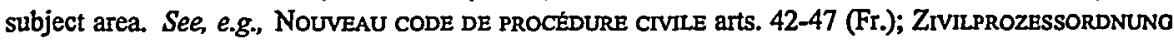
$\S \S 20-34$ (F.R.G.).

288. 433 U.S. 186 (1977).

289. See id. at 201,208 n. 30 (referring to adjudications of personal status); Brigitte $M$. Bodenheimer \& Janet Neeley-Kvarme, Jurisdiction Over Child Custody and Adoption Afier Shaffer and Kulko, 12 U.C. DAvis L. REv. 229, 239-41 (1979) ("Apart from divorces, the principal actions involving personal status are child custody and adoption proceedings.").

290. In re DES Cases, 789 F. Supp. 552, 587-89 (E.D.N.Y. 1992), appeal dismissed sub nom. In re DES Litig., 7 F.3d 20 (2d Cir. 1993). Jurisdiction is proper if (a) the forum state "has an appreciable interest in the litigation" and (b) the defendant is able to mount a defense in that state "without suffering relatively substantial hardship." Id. at 587 . A state has an "apprceiable interest" if "the litigation raises issues whose resolution would be affected by, or have a probable impact on the vindication of, policies expressed in [its] substantive, procedural or remedial laws." Id.

291. Kennedy v. Freeman, 919 F.2d 126, 129 (10th Cir. 1990). 
On the whole, however, it is remarkable how little personal jurisdiction rules have become specialized by subject area. Such mactivity is probably due to the Supreme Court, which has hinted that one rule must fit all. After all, as an overloaded court of last resort, the Supreme Court has a certain incentive to tell courts below to stop making new rules. The clearest statement was in Shaffer $v$. Heitner: "[A]11 assertions of state-court jurisdiction must be evaluated according to the standards set forth in International Shoe and its progeny."292 Yet, as it turned out, one of the implications most widely deduced from this statement-the death of transient jurisdiction-was wrong. ${ }^{293}$

\section{Guidelines for Declaring Exceptions}

One could argue that the idea of subject-area rules as exceptions to a baseline lends itself too easily to ad hoc judgments. If exceptions were recognized too readily, the predictability of jurisdictional outcomes which this Comment has argued for would vanish. Some might even feel the need for a rule that dictates when it would be acceptable to declare an exception.

While it is difficult to lay down a hard and fast rule, ${ }^{294}$ it is certainly possible to set out some guidelines for creating exceptions. Exceptions are appropriate in two main classes of cases. First, exceptions are appropriate where the rule of substantive relevance would make personal jurisdiction depend on a "fuzzy" legal distinction, defined as one where the legal rules have wavered substantially over time, and not merely a distinction which is factually difficult to make. A fuzzy distinction, by definition, cannot correspond to any clear substantive policy and is, thus, not a sound basis for deciding the existence of personal jurisdiction. For exaniple, the distinction between a breach of a contract and a tort committed in the course of performing a contract is fuzzy, given how legal rules in these areas have wavered when classifying acts imto one category or the other.

Second, an exception may be created where a policy objective has such overriding strength that a loosening of jurisdictional tests is justified by that strength. The strength of the policy objective may be measured by the degree to which other legal principles besides jurisdiction are manipulated to accommodate it. Products liability is arguably based on such an overwhelmingly strong policy. ${ }^{295}$ Similarly, the fundamental interest people have in divorce and child custody is so strong that it has led the Supreme

292. 433 U.S. at 212.

293. Transient jurisdiction is an old rule whereby in-person service of process in the forum confers personal jurisdiction on any cause of action. "Most commentators had argued that after Shaffer $v$. Heitner transient jurisdiction was no longer valid." Perdue, supra note 96, at 558 n.152. Burnham v. Superior Court, 495 U.S. 604, 608, 628 (1990), proved them wrong.

294. If one could lay down such a rule, there would be no need for exceptions: the rule that dictates when to make exceptions could itself become the rule for relatedness.

295. See supra Section V.C.1. 
Court to create a special doctrine of personal jurisdiction. ${ }^{296}$ Were it not for this doctrine, divorce and child custody cases would also be good candidates for exceptional treatment. The elimination of racial subordination is another policy objective potentially having the same degree of strength, although it has not yet given rise to any jurisdictional difficulties.

A further guideline to consider when creating exceptions is that such exceptions must support the policy goals discussed in Part II. In particular, new exceptions must maintain the principles of proportionality and nonaffiliation discussed in Part II.B. ${ }^{297}$

Those who fear a proliferation of ad hoc exceptions may also be reassured by recalling that the inodern doctrine of personal jurisdiction is almost fifty years old, having first been set forth in 1945, while the prevailing test for specific jurisdiction is over thirty-five years old. ${ }^{298}$ During that period, only one exception, the contract-tort one discussed above, has won approval by a plurality of the federal courts of appeal. ${ }^{299}$ It is thus unlikely that courts will develop additional exceptions to the baseline rule.

\section{CONCLUSION}

The concept of related contacts is central to modern personal jurisdiction law. It serves the policy goal of achieving proportionality between one's activities in a forum and one's exposure to litigation there. Sonne federal courts have applied a "but for" causation test for related contacts, but, as shown above, that test is open to serious objections because of its breadth and uncertainty and because of the difficulty of applying it to causal chains involving social activity.

A better alternative is the substantive relevance test, where a contact is related to a cause of action only if it is relevant to the plaintiff's case. For most personal jurisdiction cases, it gives satisfactory results and is thus appropriate as a precise, predictable, and narrow baseline test. However, when the substantive relevance test would tend to produce overly narrow results in certain legal subject areas, those areas can be handled by carefully designed subject-area exceptions to the general rule.

296. See Scoles \& HAY, supra note 261, at 477-80 (discussing Supreme Court cases accepting a lowered standard of personal jurisdiction for ex parte divorces); Bodenheimer \& Neeley-Kvarme, supra note 289 , at 241-48 (diseussing lowered personal jurisdiction standards for child custody and parental rights).

297. Consider a variant on the second exception which would allow suits by a nonresident of the forum on a product defect. Such an exception would allow all suits involving the product to be concentrated in the most favorable forum, violating the principle of proportionality. Such a variant would thus be unacceptable.

298. See supra notes $38-40$ and accompanying text.

299. Conversely, the products liability exception has received only tepid support. Recall that the trend of the case law is against that exception, as discussed supra in Section III.B.5. 